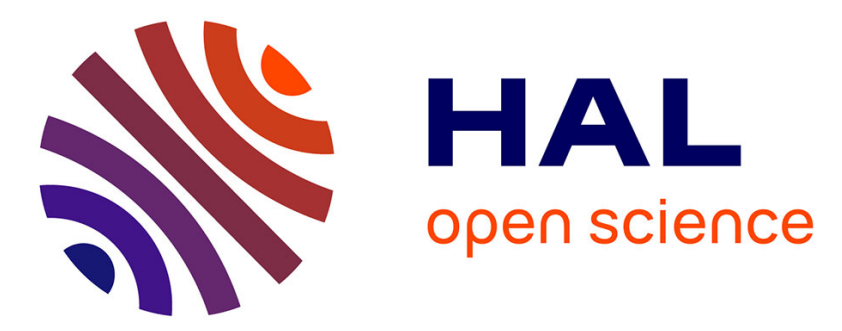

\title{
Late Cenozoic metamorphic evolution and exhumation of Taiwan
}

Olivier Beyssac, Martine Simoes, Jean-Philippe Avouac, Ken Farley, Yue-Gau Chen, Yu-Chang Chan, Bruno Goffé

\section{To cite this version:}

Olivier Beyssac, Martine Simoes, Jean-Philippe Avouac, Ken Farley, Yue-Gau Chen, et al.. Late Cenozoic metamorphic evolution and exhumation of Taiwan. Tectonics, 2007, 26 (6), pp.TC6001. 10.1029/2006TC002064 . insu-00221233

\section{HAL Id: insu-00221233 \\ https://hal-insu.archives-ouvertes.fr/insu-00221233}

Submitted on 29 Jun 2016

HAL is a multi-disciplinary open access archive for the deposit and dissemination of scientific research documents, whether they are published or not. The documents may come from teaching and research institutions in France or abroad, or from public or private research centers.
L'archive ouverte pluridisciplinaire HAL, est destinée au dépôt et à la diffusion de documents scientifiques de niveau recherche, publiés ou non, émanant des établissements d'enseignement et de recherche français ou étrangers, des laboratoires publics ou privés. 


\title{
Late Cenozoic metamorphic evolution and exhumation of Taiwan
}

\author{
Olivier Beyssac, ${ }^{1,2}$ Martine Simoes, ${ }^{1,2,3}$ Jean Philippe Avouac, ${ }^{2}$ Kenneth A. Farley, ${ }^{2}$ \\ Yue-Gau Chen, ${ }^{4}$ Yu-Chang Chan, ${ }^{5}$ and Bruno Goffé ${ }^{1}$ \\ Received 25 October 2006; revised 5 April 2007; accepted 26 June 2007; published 7 November 2007.
}

[1] The Taiwan mountain belt is composed of a Cenozoic slate belt (Hsuehshan Range units, HR, and Backbone Slates, BS) and of accreted polymetamorphic basement rocks (Tananao Complex, TC). Ongoing crustal shortening has resulted from the collision between the Chinese continental margin and the Luzon volcanic arc, which initiated $\sim 6.5 \mathrm{Ma}$ ago. The grade and age of metamorphism and exhumation are a key record of the development of the orogenic wedge. Because the Taiwan mountain belt is mostly composed by accreted sediments lacking metamorphic index minerals, quantitative constraints on metamorphism are sparse. By contrast, these rocks are rich in carbonaceaous material $(\mathrm{CM})$ and are therefore particularly appropriate for RSCM (Raman Spectroscopy of CM) thermometry. We apply this technique in addition to (U-Th)/He thermochronology on detrital zircons to assess peak metamorphic temperatures $(\mathrm{T})$ and the late exhumational history respectively, along different transects in central and southern Taiwan. In the case of the HR units, we find evidence for high metamorphic T of at least $340^{\circ}-$ $350^{\circ} \mathrm{C}$ and locally up to $475^{\circ} \mathrm{C}$, and for relative rapid exhumation with zircon (U-Th)/He ages in the range of 1.5-2 Ma. Farther east, the BS were only slightly metamorphosed $\left(\mathrm{T}<330{ }^{\circ} \mathrm{C}\right)$, and zircons are not reset for $(\mathrm{U}-\mathrm{Th}) / \mathrm{He}$. From the eastern BS to the inner TC schists, $\mathrm{T}$ gradually increases from $\sim 350^{\circ} \mathrm{C}$ up to $\sim 500^{\circ} \mathrm{C}$ following an inverted metamorphic gradient. Available geochronological constraints and the continuous thermal gradient from the $\mathrm{BS}$ to the basement rocks of the TC suggest that the high RSCM T of the TC were most probably acquired during the last orogeny, and were not inherited from a previous thermal event. Zircons yield (U-Th)/He ages of $\sim 0.5-1.2 \mathrm{Ma}$. Peak metamorphic $\mathrm{T}$ and the timing of exhumation do not show along-strike variations over the TC in the studied area. In contrast, exhumation is laterally

\footnotetext{
${ }^{1}$ Laboratoire de Géologie, ENS-CNRS, Paris, France.

${ }^{2}$ Tectonics Observatory, GPS Division, California Institute of Technology, Pasadena, California, USA.

${ }^{3}$ Now at Géosciences Rennes, Université Rennes 1 - CNRS, Rennes, France.

${ }^{4}$ Geosciences Department, National Taiwan University, Taipei, Taiwan.

${ }^{5}$ Institute of Earth Sciences, Academia Sinica, Taipei, Taiwan.

Copyright 2007 by the American Geophysical Union. 0278-7407/07/2006TC002064
}

diachronous and decreases southward in the case of the HR units. In particular, our data imply that the HR units have been exhumed by a minimum of $15 \mathrm{~km}$ over the last few Ma. In the case of the BS, they show far less cumulated exhumation and much slower cooling rates. We propose that most of the deformation and exhumation of the Taiwan mountain belt is sustained through two underplating windows located beneath the Hsuehshan Range and the TC. Our data show significant departures from the predictions of the prevailing model in Taiwan, which assumes a homogeneous critical wedge with dominant frontal accretion. Our study sheds new light on how the mountain belt has grown as a possible result of underplating mostly. Citation: Beyssac, O., M. Simoes, J. P. Avouac, K. A. Farley, Y.-G. Chen, Y.-C. Chan, and B. Goffé (2007), Late Cenozoic metamorphic evolution and exhumation of Taiwan, Tectonics, 26, TC6001, doi:10.1029/2006TC002064.

\section{Introduction}

[2] Taiwan results from the late Cenozoic collision between the Chinese continental margin and the Luzon volcanic arc (Figure 1). The Longitudinal Valley (LV) marks the suture between the two plates and separates the Taiwan mountain belt, which is composed by the accreted margin sequences west of the LV, and the Coastal Range to the east, which is a deformed remnant of the volcanic arc. This study only focuses on the metamorphic and exhumational evolution of the Taiwan mountain belt. Despite limited field access due to vertiginous topography and dense vegetation, this orogen has been relatively well-documented by thermochronologic and structural investigations, and to less extent by petrologic studies [e.g., Ho, 1986; Ernst and Jahn, 1987; Tillman and Byrne, 1995; Lo and Onstott, 1995]. It is mostly composed of metasediments with dominant marble, sandstone and slate lithologies regarded as unfavorable for developing index mineralogy under low- to medium-grade metamorphism.

[3] Metamorphic petrology has been applied to the whole Taiwan mountain belt [e.g., Ernst, 1983; Warneke and Ernst, 1984; Ernst and Jahn, 1987], but it only provided significant quantitative results on few outcrops with spectacular mineralogy, all in mafic bodies or gneisses located in eastern Taiwan [Liou et al., 1975; Ernst and Jahn, 1987; Yui and Lo, 1989]. These studies suggested a general eastward increase of metamorphic grade [e.g., Ernst and Jahn, 1987], from diagenetic conditions in the Western Foothills (WF) to the upper greenschist facies in eastern Taiwan. This gradient 


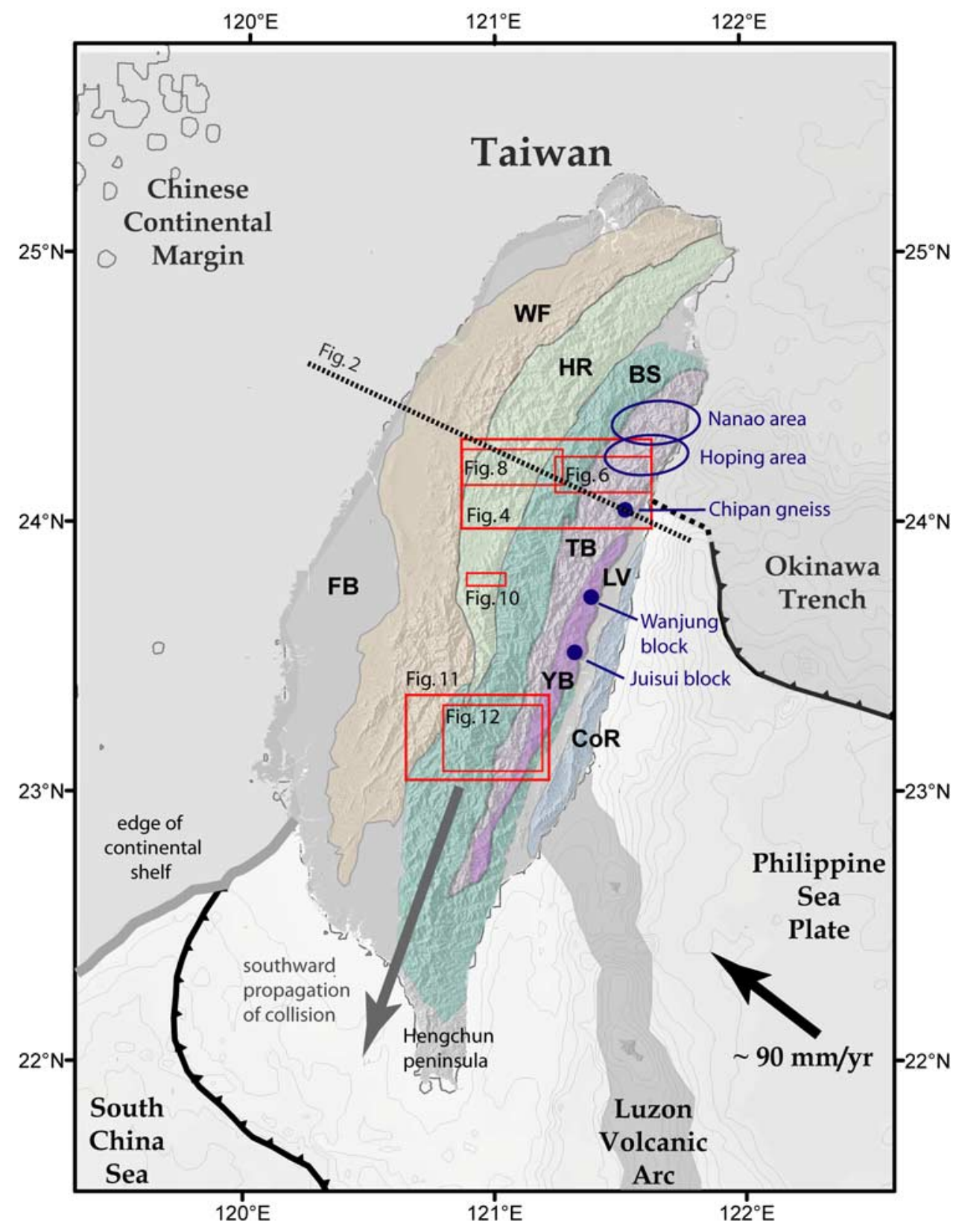

Figure 1. Geological map of Taiwan showing the main tectonostratigraphic ensembles (FB, foreland basin; WF, western foothills; HR, Hsuehshan Range units; BS, Backbone slates; TB, Tailuko belt; YB, Yuli belt; LV, longitudinal valley; CoR, Coastal Range). The Tananao complex (TC) is composed of the TB and YB. The location of the cross section shown in Figure 2 is indicated by the black dashed line. Red boxes indicate location of the maps shown in Figures 4, 6, and 8 (central cross-island highway), 10 (Choushui transect), and 11 and 12 (southern cross-island highway). The Nanao area, Chipan gneiss, and the Juisui and Wanjung exotic blocks are localities were advanced petrologic and/or geochronologic investigations are available. Modified after Ho [1988].

is evidenced by the successive appearance of chlorite, epidote and biotite, together with an increasing cristallinity of white micas and an increasing graphitization degree of carbonaceous matter [Ernst, 1983; Warneke and Ernst, 1984; Yui et al., 1996], but cannot be quantitatively clearly documented because of the lack of index mineralogy in the metasediments. In particular, the Hsuehshan Range units (hereafter HR), located at the westernmost portion of the Taiwan mountain belt (Figures 1 and 2), are usually considered as weakly metamorphosed, although some 


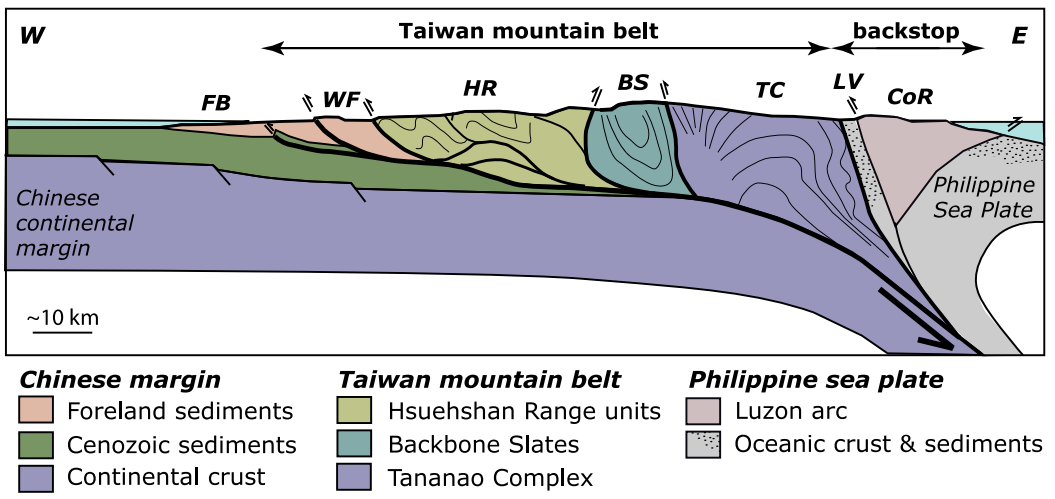

Figure 2. Schematic geological section of Taiwan along the central cross-island highway (see Figure 1 for location). FB, foreland basin; WF, western foothills; HR, Hsuehshan Range units; BS, Backbone slates; TC, Tananao complex; LV, longitudinal valley; CoR, Coastal Range. Vertical distances are exaggerated. Modified after Malavieille and Trullenque [2007].

authors have suggested, on the basis of qualitative arguments, that the core of these units have undergone a more significant metamorphism [Clark et al., 1993; Yui et al., 1996; Tsao, 1996]. This observation breaks the eastward increasing metamorphic trend across the orogen suggested in previous studies, and challenges the view that the Taiwan mountain belt can be considered as a critical homogenous brittle wedge growing essentially by frontal accretion of material, with only up to $25 \%$ underplating as initially proposed by Dahlen and Barr [1989], Barr and Dahlen [1989] and Barr et al. [1991]. As a matter of fact, little consideration has been paid in previous models of mountain building of the Taiwan orogen to the metamorphism and exhumation of the HR units, and the earlier thermokinematic model of Dahlen and Barr [1989], Barr and Dahlen [1989] and Barr et al. [1991] only provides a satisfying explanation for the distribution of metamorphic grades and cooling rates within the eastern Taiwan mountain belt (Figures 1 and 2). In addition, recent studies based on structural arguments [Hwang and Wang, 1993; Crespi et al., 1996], or based on the distribution of shortening across the range [Simoes and Avouac, 2006] and on thermochronological data [Fuller et al., 2006] have suggested that the contribution of underplating to the growth of the orogen may have been underestimated in these earlier models.

[4] Although metamorphism has been relatively well studied in Taiwan, in particular in terms of chronology from extensive low-temperature thermochronologic investigations, it has been essentially qualitatively described, with currently almost no available quantitative constraints on the physical pressure-temperature (P-T) conditions. Such data are a key record of the development of the orogenic wedge and therefore provide crucial constraints to test models of mountain building. Here we take advantage of recent analytical developments to estimate peak metamorphic temperatures $(\mathrm{T})$ and the low-T cooling history of the metasediments of the Taiwan mountain belt, using respectively RSCM (Raman spectroscopy of carbonaceous material) thermometry and (U-Th)/He thermochronology on zircon detrital grains $(\mathrm{ZHe})$. RSCM has recently been shown to be a reliable and accurate technique to estimate peak metamorphic $\mathrm{T}$ in metasediments [Beyssac et al., 2002a, 2004; Negro et al., 2006]. Carbonaceous material $(\mathrm{CM})$ is widespread in metasediments and the RSCM thermometry is based on the quantitative characterization of graphitization during metamorphism, which has been shown to be a T-dependant process [Beyssac et al., 2002a]. RSCM allows for the accurate determination of peak metamorphic $\mathrm{T}$ experienced by a metasediment in the range of $330^{\circ}-640^{\circ} \mathrm{C}$ with an error of $\pm 50^{\circ} \mathrm{C}$ [Beyssac et al., 2002a], and to detect relative $\mathrm{T}$ variations between samples with a $\sim 10^{\circ}-15^{\circ} \mathrm{C}$ precision [Beyssac et al., 2004]. ZHe thermochronology on detrital grains provides constraints on the late exhumation of these rocks [e.g., Reiners et al., 2004] and may seem particularly well suited to Taiwan where metamorphic $\mathrm{T}$ have been generally assumed to be low. Combining both methods provides quantitative insights into the metamorphic and exhumation history of the Taiwan mountain belt, from the deep burial history of these rocks (RSCM) up to their late exhumational stages (thermochronology). In this study, we place a particular emphasis on the metamorphism and exhumation of the Hsuehshan Range units.

[5] Hereafter, we first present the regional geological background and summarize the existing literature before introducing the analytical methods and their particular application to the Taiwan orogen. Results are then shown along three main transects across the mountain belt. We then discuss the significance of our data, in particular that of RSCM T with respect to the late Cenozoic orogeny. We finally propose a qualitative model of the late Cenozoic metamorphic evolution of the Taiwan mountain belt, which is tested more quantitatively in a related paper [Simoes et al., 2007].

\section{Geological Setting and Overview of Existing Data}

\subsection{Geological Setting}

[6] The island of Taiwan is located at the boundary between the Philippine Sea Plate and the Eurasian Plate, 
which converge at a rate of $\sim 90 \mathrm{~mm} / \mathrm{yr}$ in a NW-SE direction [Sella et al., 2002] (Figure 1). To the southwest of Taiwan, the South China Sea subducts beneath the Philippine Sea Plate along the Manila Trench, building up the Luzon volcanic arc. The ongoing consumption of the South China Sea led to the collision of the Chinese continental margin with the Luzon volcanic arc [e.g., Sibuet and Hsu, 2004; Shyu et al., 2005b], and resulted in the building of the Taiwan mountain belt which absorbs a longterm ( $\sim 2 \mathrm{Ma})$ shortening rate of $\sim 42 \mathrm{~mm} / \mathrm{yr}$ [Simoes and Avouac, 2006]. The remaining $\sim 48 \mathrm{~mm} / \mathrm{yr}$ are to be accommodated on the Philippe Sea Plate side of the plate boundary, in particular on the LV Fault [Shyu et al., 2005a], across the Coastal Range (CoR) and offshore eastern Taiwan [Malavieille et al., 2002; Simoes and Avouac, 2006]. The age of initiation of the collision is still debated and estimates vary widely depending on authors and on the criterion used: $\sim 4 \mathrm{Ma}$ [Chi et al., 1981], $\sim 6.5 \mathrm{Ma}[$ Lin et al., 2003] or even $\sim 8 \mathrm{Ma}$ [Sibuet and Hsu, 2004]. Because of the obliquity of the continental margin relative to the subduction zone (Figure 1), the collision has propagated southward at rates estimated to be of $\sim 31 \mathrm{~mm} / \mathrm{yr}$ as recorded in the late Cenozoic filling of the foreland basin [Simoes and Avouac, 2006] and up to 60 [Byrne and Liu, 2002] or $90 \mathrm{~mm} / \mathrm{yr}$ [Suppe, 1981, 1984] based on the geometry of the passive margin and the Luzon volcanic arc to the south of Taiwan. Different E-W transects across the mountain belt may thus be interpreted as representing different stages of development of the orogenic wedge [Suppe, 1981].

[7] The Taiwan mountain belt develops west of the LV suture zone and is composed of several tectono-stratigraphic units [Ho, 1986], which are from west to east (1) the foreland basin (FB) and western foothills (WF), (2) the slate belt including the Hsuehshan Range units (HR) and the Backbone Slates (BS), and (3) the Tananao Complex (TC) constituted of pre-Tertiary basement (Figures 1 and 2). We use the terminology 'Backbone' for consistency with some earlier tectono-stratigraphic classifications, in particular that of $\mathrm{Ho}$ [1988]. Hereafter, the abbreviations 'BS' and 'HR' refer to these two different tectonostratigraphic provinces of the slate belt. In particular, "HR' is used to refer to the units outcropping within the Hsuehshan Range physiographic range (Figure 2). East of the LV suture zone, the CoR is the remnant of the Luzon arc and is mainly composed of volcanic rocks and melanges related to the collision [Page and Suppe, 1981]. In this study, we only focus on the Taiwan mountain belt, which has been built through the accretion of the Cenozoic metasediments of the slate belt $(\mathrm{HR}+\mathrm{BS})$ to the west, and through the accretion of the pre-Tertiary basement (TC) to the east (Figure 2). The TC is exposed as a north-south $250-\mathrm{km}$-long ensemble with a maximum width of $30 \mathrm{~km}$ to the north, decreasing to $10 \mathrm{~km}$ to the south, while the slate belt is $\sim 350 \mathrm{~km}$ long with a maximum width of $50 \mathrm{~km}$ along the northernmost section (Figure 1). The TC has a complex polymetamorphic history and one of the challenges of this study is to decipher the metamorphic signal that has resulted from the late Cenozoic orogeny. By contrast, the Cenozoic units within the slate belt have only experienced Cenozoic metamorphism and are usually thought to have undergone a very low-grade metamorphism [Ernst and Jahn, 1987; Faure et al., 1991].

\subsection{Stratigraphy}

[8] The stratigraphy of Taiwan has been well-documented [e.g., Ho, 1986, 1988]. However, because of limited field access and outcrops, as well as scarce occurrences of paleontologic indicators, lateral correlations are difficult. In this section, we provide an outline of the stratigraphy in both the slate belt and the pre-Tertiary TC, since such an understanding not only is critical for a proper application of our analytical techniques, but also provides key information on mountain building as well. Table 1 summarizes the stratigraphy of the Taiwan mountain belt as regionally defined in the geological map of [Ho, 1986, 1988], and reports the main metamorphic mineralogy encountered in the different units [Ernst and Jahn, 1987] (also this study). Some lateral stratigraphic facies variations do exist in the Taiwan mountain belt and we chose to use the unified terminology adopted by Ho [1988].

[9] Because the pre-Tertiary TC has undergone a complex polymetamorphic history, its stratigraphy is not easy to decipher. The rocks are late Paleozoic in age and two belts have been distinguished on stratigraphic and metamorphic criteria: the Tailuko Belt to the west and the Yuli Belt to the east (Figure 1). In the Tailuko Belt, the general stratigraphy consists of marbles intercalated locally by schists and dolomites, followed upward by black and green schists intercalated with marbles and metasandstones. Some gneisses (quartzofeldspathic paragneisses and metagranitic orthogneisses), amphibolites and other granitic rocks locally outcrop in NE Taiwan [Ernst, 1983; Liou et al., 1981]. The Yuli belt on the other hand is constituted almost exclusively of black schists with locally intercalated metasandstones and greenschists [Stanley et al., 1981; Warneke and Ernst, 1984] in addition to blueschists and mafic to ultramafic exotic blocks that are discordant with the surrounding host rocks [Liou et al., 1975]. These two belts are usually regarded as having contrasted metamorphic evolutions: high-pressure-low-temperature conditions in Yuli, and high-temperature-low-pressure conditions in Tailuko [e.g., Ho, 1986, 1988; Ernst and Jahn, 1987].

[10] The slate belt includes the HR units to the west and the BS to the east (Figures 1 and 2). The BS is composed of the Eocene Pilushan Formation and of the early to middle Miocene Lushan Formation [Ho, 1988]. The Pilushan Formation is composed mainly by slates and phyllites with some metamorphosed sandstone interbeds (Table 1). The Lushan Formation consists of black to dark grey argillites, slates, and phyllites with occasional interbeds of dark grey compact sandstone and disseminated marly nodules. Most of the BS is located on the western side of the pre-Tertiary TC, except a narrow lense of Eocene Pilushan Formation occurring between the LV and the eastern flank of the TC in southern Taiwan (Figure 1). Although clear polarity criteria are hardly recognizable in the field, overturned conglomerates of the BS have been locally described to lie unconformably over the TC basement [Suppe, 1976]. This 
Table 1. Simplified Stratigraphy of the Taiwan Mountain Belt Over the Studied Area ${ }^{a}$

\begin{tabular}{|c|c|c|c|c|}
\hline Age & Formation & Lithology & Thickness & Mineralogy \\
\hline Miocene & Lushan (BS) & slates, shales and argilites & $1000 \mathrm{~s} ? \mathrm{~m}$ & chlorite, white mica \\
\hline \multirow[t]{4}{*}{ Oligocene } & $\begin{array}{l}\text { Shuichangliu and } \\
\text { eq. (HR) }\end{array}$ & shales and argilites & $>1500 \mathrm{~m}$ & chlorite, white mica \\
\hline & Likuan (BS) & sandstones and siltstones & $900 \mathrm{~m}$ & chlorite, white mica \\
\hline & Meichi/Paileng (HR) & sandstones/slates & $700-2600 \mathrm{~m}$ & (chlorite, white mica) \\
\hline & Chiayang (HR) & slates (sandstones beds) & $3000 \mathrm{~m}$ & chlorite, muscovite, detrital biotite \\
\hline \multirow[t]{3}{*}{ Eocene } & Tachien (HR) & sandstones (slates beds) & $2700 \mathrm{~m}$ & chlorite, muscovite, detrital biotite \\
\hline & Shihpachungchi (HR) & slates/sandstones & $?$ & chlorite, white mica \\
\hline & Pilushan (BS) & $\begin{array}{l}\text { slates (sandstones and } \\
\text { conglomerates lenses, } \\
\text { volcanic nodules) }\end{array}$ & $1000 \mathrm{~s} ? \mathrm{~m}$ & chlorite, muscovite, green biotite \\
\hline \multirow[t]{5}{*}{$\begin{array}{l}\text { Late Paleozoic } \\
\text { to Mesozoic }\end{array}$} & Tailuko belt & $\begin{array}{l}\text { black and green schists, } \\
\text { metacherts and } \\
\text { metasandstones }\end{array}$ & $?$ & $\begin{array}{l}\text { chlorite, muscovite, green }(\mathrm{W}) \text { to } \\
\text { red }(\mathrm{E}) \text { biotite, increasing epidote } \\
\text { to the } \mathrm{E}\end{array}$ \\
\hline & & marbles (schists intercalations) & ? & $\begin{array}{l}\text { chlorite, muscovite, } \\
\text { brown to red biotite, epidote }\end{array}$ \\
\hline & & $\begin{array}{l}\text { gneisses, migmatites, } \\
\text { amphibolites }\end{array}$ & $?$ & see Lo and Onstott [1995] \\
\hline & Yuli belt & $\begin{array}{l}\text { mainly blackschists, } \\
\text { sandstones }\end{array}$ & $?$ & $\begin{array}{l}\text { chlorite, muscovite, green (W) to } \\
\text { brown (E) biotite, increasing } \\
\text { epidote to the E }\end{array}$ \\
\hline & & $\begin{array}{l}\text { mafic rocks, amphibolites, } \\
\text { blueschists }\end{array}$ & $?$ & see text \\
\hline
\end{tabular}

${ }^{a}$ Lithology and thicknesses are taken from Ho [1988]. Mineralogy is given after Ernst [1983] and Tillman and Byrne [1995]. These data are completed by our own observations. BS, Backbone slates; HR, Hsuehshan Range units.

suggests that the contact between the two units is stratigraphic and that the whole series is overturned. This is also supported by the field investigations of [Ernst, 1983] who observed overturned clastic textures within the whole eastern BS. To the west of the BS, the HR units are composed of the Eocene Shihpachungchi and Tachien sandstones with intercalated slates, conformably overlain by the Oligocene Chiayang Formation constituted of a thick series of slates with minor fine-grained sandstone intercalations. These units are conformably overlain by the Oligocene Meichi sandstone and the Oligocene Paileng sandstone present in the westernmost portion of the HR units. At the top of the sequence is the upper Oligocene argillaceous Shuichangliu Formation.

\subsection{Structural Framework}

[11] Numerous studies have been dedicated to the structural geology of the Taiwan mountain belt, with particular emphasis on the slate belt [Clark et al., 1993; Tillman and Byrne, 1995; Fisher et al., 2002] or on the pre-Tertiary TC [Pulver et al., 2002; Crespi et al., 1996]. Most studies have focused locally on these two main provinces and rare are those that have integrated structural observations at the scale of the whole Taiwan mountain belt [Ernst and Jahn, 1987; Faure et al., 1991]. Kinematic indicators of left-lateral shear have been found essentially in the eastern TC units along the $\mathrm{LV}$, and are related to the slight obliquity $\left(\sim 10^{\circ}\right)$ between the direction of transport and the structural trend in Taiwan [e.g., Faure et al., 1991; Pulver et al., 2002].

[12] The structural evolution of the slate belt has been studied in great detail along the central cross-island highway [Clark et al., 1993; Tillman and Byrne, 1995; Fisher et al., 2002; Yue et al., 2005] as well as along the southern cross-island highway [Stanley et al., 1981; Tillman and Byrne, 1995, 1996; Fisher et al., 2002]. The central highway offers the most complete profile through the whole wedge (Figures 1 and 2) as the HR units are absent from the southern section (Figure 1). Indeed, the HR units disappear southward as they may still be buried where the collision is younger and less mature (Figure 1) [Clark et al., 1993; Simoes and Avouac, 2006]. Previous studies have shown that in the HR units the strain history is co-axial and deformation occurs by pure shear [Clark et al., 1993; Tillman and Byrne, 1995]. By contrast, simple shear prevails in $\mathrm{BS}$ with inclined asymmetric westward verging 
folds and moderately SE-dipping axial planar pressure solution cleavage, consistent with top-to-the-west kinematic criteria. The BS and the HR units are separated by the Lishan fault. If the Lishan fault is a very well marked morphologic lineament in Taiwan (Figure 1), it is however hardly identifiable in the field owing to very similar lithologies (slates) in both the hangingwall and the footwall. This contact has most probably experienced a polyphase history, and appears to have behaved as an east vergent back thrust with some left-lateral strike-slip component [Clark et al., 1993; Tillman and Byrne, 1995; Lee et al., 1997], making the Hsuehshan Range a regional-scale pop-up structure [Clark et al., 1993].

[13] The contact between the TC and the BS is more likely a stratigraphic unconformity [Suppe, 1976; Ho, 1986; Clark et al., 1993; Tillman and Byrne, 1995; Crespi et al., 1996; Yue et al., 2005]. The structural evolution of the preTertiary TC is more complex to decipher as it results from a polyphase tectonic history [Faure et al., 1991]. Recent Cenozoic deformation is characterized by a NE-SW trend and a top-to-the-NW shear [Faure et al., 1991]. On a regional scale, the interpretations are rather different as Faure et al. [1991] consider that deformation through the TC is in continuity with that of the slate belt and is manifested mainly as a top-to-the-NW thrusting and folding, while Pulver et al. [2002] consider that deformation has been partitioned between the slate belt and the TC. These latter propose that owing to the oblique collision, the preTertiary TC resulted from left-lateral extrusion between the slate belt and the CoR. Finally, the nature of the contact separating the eastern TC from the LV is still a matter of debate [e.g., Crespi et al., 1996; Shyu et al., 2006; Simoes et al., 2007]. Additional structural details on the three investigated transects, including our own observations, will be subsequently given in the following sections to directly replace the data provided in this study into a common structural framework.

\subsection{Existing Metamorphic and Chronologic Constraints}

[14] Metamorphic petrology in Taiwan has been considerably studied in the seventies and early eighties, and the reader is referred to the excellent review by Ernst and Jahn [1987]. In addition, thermochronology has been performed, in particular fission tracks and K-Ar dating as well as other various radiometric methods. Some of these petrologic and thermochronological studies were dedicated to the metasediments [Ernst, 1983; Warneke and Ernst, 1984; Tsao, 1996; Yui et al., 1996; Liu et al., 2001; Yui, 2005; Fuller et al., 2006], and others focused on the gneisses, mafic and blueschist bodies scarcely outcropping within the metasediments of the easternmost Taiwan mountain belt (Figure 1) [Liou et al., 1975, 1981; Yui and Lo, 1989; Lo and Onstott, 1995; Wang et al., 1998; Hwang et al., 2001].

[15] As mentioned previously, the slate belt and most of the TC are characterized by mineralogical assemblages unsuited to conventional petrologic studies (Table 1). However, Ernst [1983] and Warneke and Ernst [1984] were able to identify a general eastward increasing metamorphic gra- dient from BS to the inner TC. This metamorphic gradient was evidenced through (1) appearance of biotite at the contact between the slate belt and the TC, (2) documentation of an eastward progressive transition from celadonite-rich to muscovite-rich white mica composition in presence of chlorite or biotite, (3) variations of both major and trace elements partitioning in phyllosilicates, and (4) increasing degree of graphitization of $\mathrm{CM}$ as characterized by X-ray diffraction along the southern profile. These authors have proposed physical conditions of metamorphism of $\sim 325^{\circ} \mathrm{C} /$ $\sim 3$ kbar in the western TC (Tailuko Belt) increasing eastward up to $\sim 425^{\circ} \mathrm{C} / \sim 4 \mathrm{kbar}$ along the central highway, and of $\sim 200^{\circ} \mathrm{C} / \sim 2 \mathrm{kbar}$ in the slate belt increasing up to $\sim 400^{\circ} \mathrm{C} / \sim 3 \mathrm{kbar}$ in TC (Tailuko Belt) along the southern transect, with slightly higher pressures in eastern TC (Yuli Belt). Moreover, Ernst and Jahn [1987] proposed physical conditions of metamorphism of $\sim 150^{\circ} \mathrm{C} / \sim 1 \mathrm{kbar}$ in the WF, $\sim 260^{\circ} \mathrm{C} / \sim 2 \mathrm{kbar}$ in the $\mathrm{HR}$ units, and $\sim 300^{\circ} \mathrm{C} / \sim 4 \mathrm{kbar}$ for the BS. Such an eastward increasing metamorphic gradient has been questioned by investigations on metamorphism at the scale of the whole mountain belt using Raman spectroscopy of CM [Yui et al., 1996], illite cristalinity [Tsao, 1996] and graphite-calcite isotopic thermometry [Yui, 2005]. These studies demonstrate that the metamorphic pattern in the slate belt is more complex, with a greenschist facies core in the HR units supported by the presence of biotite [Clark et al., 1993]. Metamorphism then decreases to prehnite-pumpellyite facies in the western BS, and then reincreases eastward to greenschist facies in the easternmost BS. However, these petrologic estimates are essentially qualitative and need to be better quantified. In the case of thermochronological investigations, K-Ar dating has been performed along both central and southern cross-island highways on the clay fine fraction $(<2 \mu \mathrm{m})$ of white micas. A large data set is available [Tsao, 1996] (Table S2 ${ }^{1}$ ) and an arguable closure $\mathrm{T}$ of $350^{\circ} \mathrm{C}$ was proposed by the authors. These data show a complete resetting of the K-Ar ages in the TC and in the core of the HR whereas most of the BS exhibits only partially to non-reset ages. A similar spatial distribution of reset and non-reset ages is obtained from zircon fission tracks (ZFT) [Liu et al., 2001] (auxiliary material Table $\mathrm{S}^{1}$ ).

[16] The best quantitative petrologic and thermochronologic constraints were obtained on the gneissic and granitic intrusions from the northeastern TC, in the Tailuko Belt (Nanao area, Figure 1), as well as on mafic/blueschist exotic blocks located in the Yuli Belt along the suture zone (Figure 1). P-T estimates in the Nanao area are of $\sim 530^{\circ}-$ $550^{\circ} \mathrm{C} / 5-7 \mathrm{kbar}$ for the mineral matrix in the gneiss, with higher-grade conditions $\left(<660^{\circ}-690^{\circ} \mathrm{C} />8.3-8.8 \mathrm{kbar}\right)$ recorded by kyanite and staurolite inclusions within garnet [Hwang et al., 2001]. No P-T estimates are available in the gneisses of the Chipan area farther south along the central cross-island highway (Figure 1). In the Yuli Belt along the $\mathrm{LV}$, spectacular mineralogical assemblages were found in the Juisui area including garnet amphibolites and glaucophane

\footnotetext{
${ }^{1}$ Auxiliary materials are available at ftp://ftp.agu.org/apend/tc/ 2006 tc002064.
} 
blueschists. The petrology of these rocks has been studied in detail by Liou et al. [1975]. In the Northern Wanjung exotic tectonic block, Yui and Lo [1989] document jadeite-bearing pyroxenes (omphacite) within a metagabbro. Maximum P-T conditions are estimated to $500^{\circ}-550^{\circ} \mathrm{C} / \sim 12 \mathrm{kbar}$ for the Juisui blueschists and $500^{\circ}-550^{\circ} \mathrm{C} / 14 \mathrm{kbar}$ for the Wanjung block (O. Beyssac et al., High-pressure metamorphism in Taiwan: From oceanic subductionto arc-continent collision?, manuscript submitted to Terra Nova, 2007) (hereinafter referred to as Beyssac et al., submitted manuscript, 2007). In addition, geochronologic and thermochronologic data are abundant in both the gneisses to the north [Jahn et al., 1986; Juang and Bellon, 1986; Lo and Onstott, 1995; Wang et al., 1998] and the blueschists from the Juisui area [Jahn et al., 1981; Lo and Yui, 1996]. The gneisses have a complex poly metamorphic history with at least two major thermal events occurring around 80-90 Ma (Cretaceous) and during the late Cenozoic. During the most recent one, thermal metamorphism has partially reset ${ }^{40} \mathrm{Ar}-{ }^{39} \mathrm{Ar}$ ages on biotite, but not on muscovite nor on hornblende in the Nanao area (Figure 1). In the case of the gneisses from the Chipan area, biotites were fully reset for ${ }^{40} \mathrm{Ar}-{ }^{39} \mathrm{Ar}(7.7 \mathrm{Ma})$, but ages obtained on muscovites and hornblendes were only partially reset [Lo and Onstott, 1995]. Lo and Onstott [1995] carefully characterized the phyllosilicates used for dating and showed that a significant fraction has systematically recrystallized and/or has been replaced by chlorite. In particular, they evidenced the presence of second generation phengites as well as actinolitic rims on hornblendes and attributed them late Cenozoic ${ }^{40} \mathrm{Ar}^{39}{ }^{39} \mathrm{Ar}$ ages $(\sim 6.4 \mathrm{Ma}$ and $\sim 7.8$ Ma respectively). Lo and Onstott [1995] suggest that ${ }^{40} \mathrm{Ar}-{ }^{39} \mathrm{Ar}$ resetting of these second-generation minerals may indicate that these rocks have been to $\mathrm{T}$ of up to $450^{\circ}-500^{\circ} \mathrm{C}$ during the most recent orogeny in Taiwan. In the case of the exotic blocks of the Yuli Belt, Rb-Sr ages on blue amphiboles in glaucophane blueschists cluster around 8-14 Ma [Jahn et al., 1981] and ${ }^{40} \mathrm{Ar}^{39}{ }^{39} \mathrm{Ar}$ dating on different generations of phengites are of 10-11 Ma [Lo and Yui, 1996]. These geochronological ages are prior to the late Tertiary collision in Taiwan. In fact, these rocks found along the suture zone may record metamorphic conditions that prevailed during the earlier phase of oceanic subduction prior to the collision (Beyssac et al., submitted manuscript, 2007). These exotic blocks may therefore not be simply used to assess thermal and metamorphic conditions during recent mountain building in Taiwan.

[17] To summarize, late Cenozoic metamorphism has probably affected the whole mountain belt with a generally increasing metamorphic gradient eastward from the WF to the eastern pre-Tertiary TC, despite a local relatively high metamorphic grade within the HR units. In the northern TC (Nanao area), intensity of metamorphism was probably weaker than in central Taiwan, either because of the complexities associated with the reversal of subduction vergence in northeastern Taiwan [Suppe, 1984] or because this area is closer to the front of the mountain belt [Lo and Onstott, 1995]. In the following sections we provide new robust quantitative constraints on the metamorphic evolu- tion and on the shallow exhumation stages of the Taiwan mountain belt along three transects.

\section{Methods}

\subsection{Referencing the Samples to a Clear Geographical and Structural Framework}

[18] In order to compare and homogenize all the data from this study with those from the literature, we have tried to refer all the data to a common geographical and structural reference frame. Because some of the previous studies do not provide geographic coordinates for samples, we estimated their position by georeferencing published maps (auxiliary material Tables S1 and S2). We have listed in the auxiliary materials the thermochronologic data georeferenced in this study: ZFT on detrital grains (Table S1: Tsao [1996] and Liu et al. [2001]) and K-Ar dating (Table S2: Tsao [1996]). The uncertainties on the estimated locations vary from one source to another depending on the precision and details of the source maps. For each of our own samples, horizontal position (WGS 84 system) and altitude were measured with a hand-held GPS. Altitudes were systematically compared and eventually corrected with high-resolution topographic maps. In the following, all data are projected on a N110 transect perpendicular to the main structural trend, and geographical distances are given with respect to the suture zone (LV).

[19] At each sampling site, a careful examination of structural deformation was carried on and we systematically measured the bedding and/or the foliation. We also characterized the ductile deformation by the direction of stretching lineation and associated sense of shear whenever possible. Because landslides are ubiquitous within the Taiwan mountain belt and can therefore severely affect in situ structural measurements, we averaged our observations from different but coherent outcrops, and compared them with existing data.

\subsection{RSCM Method}

[20] During diagenesis and metamorphism, CM present in the initial sedimentary rock is progressively transformed into graphite (graphitization). The corresponding progressive evolution of the degree of organization of CM is considered to be a reliable indicator of metamorphic $\mathrm{T}$ [Wopenka and Pasteris, 1993; Beyssac et al., 2002a]. Because of the irreversible character of graphitization (CM is tending toward the thermodynamic stable phase which is graphite), CM structure is not sensitive to the retrograde path of the rock up to the surface, and therefore primarily depends on the maximum $\mathrm{T}$ reached during metamorphism [Beyssac et al., 2002a]. It has also been observed that samples collected from neighboring outcrops with clearly different strains have the same degree of graphitization, indicating that deformation does not significantly affect the structural organization of the $\mathrm{CM}$ in metamorphic rocks [Beyssac et al., 2002b]. Raman microspectroscopy is the most suitable technique to study natural $\mathrm{CM}$ in situ within thin sections. The first-order Raman 


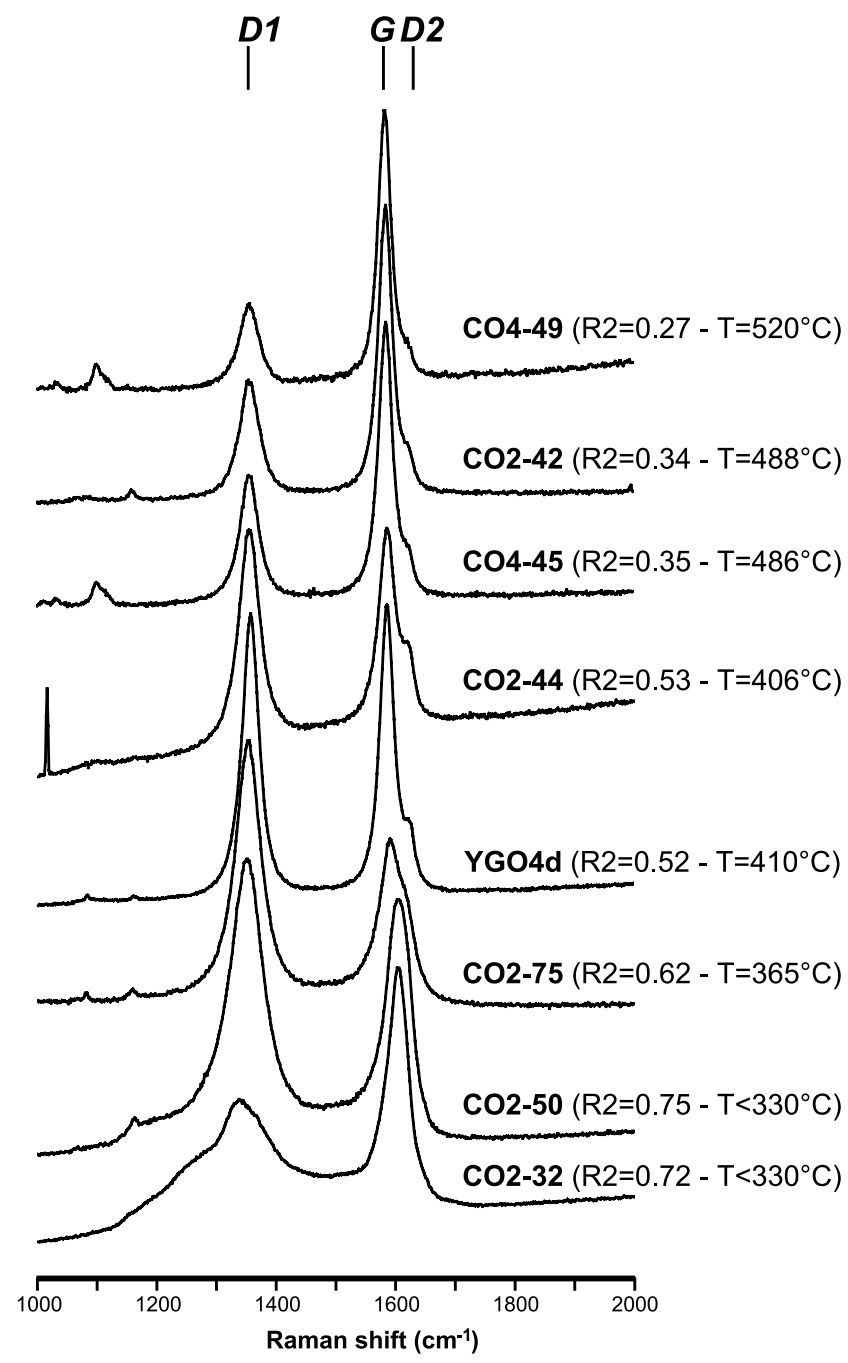

Figure 3. Raman spectra of carbonaceous material (CM) obtained along the central cross-island highway section from samples in the HR (C02-42, C0244), BS (C02-32, C02-50), and TC (C02-75, YG04d, C04-45, C04-49). Positions of G, D1, and D2 bands are indicated. For each spectrum, the R2 ratio and corresponding RSCM temperature calculated from the depicted $\mathrm{CM}$ spectrum are indicated. See Beyssac et al. [2002a] for details regarding RSCM thermometry.

spectrum of disordered $\mathrm{CM}$ exhibits a graphite $\mathrm{G}$ band at $1580 \mathrm{~cm}^{-1}, \mathrm{E}_{2 \mathrm{~g} 2}$ mode corresponding to in-plane vibration of aromatic carbons, and several defect bands (D1, D2, D3), corresponding to "physico-chemical defects" [e.g., Beyssac et al., 2003a, and references therein]. The structural organization of $\mathrm{CM}$ can be quantified through the $\mathrm{R} 2$ parameter defined as the relative area of the main defect band D1 $(\mathrm{R} 2=$ $\mathrm{D} 1 /[\mathrm{G}+\mathrm{D} 1+\mathrm{D} 2]$ peak area ratio). A linear correlation between this R2 parameter and metamorphic $\mathrm{T}$ was calibrated using samples from different regional metamorphic belts with well-known P-T conditions with $\mathrm{T}$ ranging from $330^{\circ}$ to $640^{\circ} \mathrm{C}$ (RSCM method [Beyssac et al. [2002a]). $\mathrm{RSCM}$ can be applied to metasediments of pelitic litholo- gies in which the $\mathrm{CM}$ precursor is mainly a kerogen. The accuracy on $\mathrm{T}$ is $\pm 50^{\circ} \mathrm{C}$ due to uncertainties on petrologic data used for the calibration. The relative uncertainties on $\mathrm{T}$ are much smaller, probably around $10^{\circ}-15^{\circ} \mathrm{C}$ [Beyssac et al., 2004], allowing for a precise estimate of thermal metamorphic gradients [Bollinger et al., 2004].

[21] Raman spectra were obtained in Georges Rossman's laboratory (GPS division, Caltech, Pasadena, California, USA) using a Renishaw RM 1000 microspectrometer. We used the 514-nm wavelength of a Spectra Physics argon laser, and the laser incident beam was depolarized with a double wedge quartz depolarizer placed before the microscope. The laser power at the sample surface was set around $1 \mathrm{~mW}$ and the laser was focused on the sample by a DMLM Leica microscope with a $100 \times$ magnification objective $(\mathrm{NA}=0.90)$. The Rayleigh diffusion was eliminated by notch filters, and to achieve the best spatial resolution the spectrometer entrance slit was closed down to $10-15 \mu \mathrm{m}$ to reach a nearly confocal configuration. The signal was finally dispersed using a $1800 \mathrm{gr} / \mathrm{mm}$ grating and analyzed by a Peltier cooled CCD detector. Before each session the spectrometer was calibrated with a silicon standard. Because Raman spectroscopy of $\mathrm{CM}$ can be affected by several analytical mismatches, we followed closely the analytical and fitting procedures described by Beyssac et al. [2002a, 2003a]. Measurements were done on polished thin sections cut perpendicularly to the bedding and/or schistosity and CM was systematically analyzed below a transparent adjacent mineral, generally quartz. Ten spectra were generally recorded for each sample in the extended scanning mode $\left(1000-2000 \mathrm{~cm}^{-1}\right)$ with acquisition times from 30 to $60 \mathrm{~s}$. Spectra were then processed using the software Peakfit and an example of decomposition is given in Beyssac et al. [2003a]. Because the original calibration was performed using a totally different system, a DILOR $\mathrm{XY}$ spectrometer with a $50 \times$ objective and a polarized laser, we re-measured all the samples used for the original calibration at Caltech. We find that the difference of mean R2 value calculated for $\sim 10$ spectra is always lower than the standard deviation calculated on each set of analyses. We therefore consider that the instrumental effect on our measurements, if any, is negligible.

[22] As shown in Figure 3, there is a wide range of graphitization degrees over the Taiwan mountain belt, from very poorly organized $\mathrm{CM}$ in the $\mathrm{BS}$ to poly crystalline graphite in the TC. Such an evolution is very similar to that described by Beyssac et al. [2002b] in the Western Alps (Italy), and the reader interested in graphitization should refer to this paper. However, it is important to note that we have observed at a few localities some detrital graphite that was not taken into account in our results. Such graphite was commonly found in the slates intercalated within the Tachien sandstone and within the sandstone itself (core of the HR units). It was easily recognized by its morphology (small grains and/or elongated flakes) and its spectral signature (unusually high degree of ordering). However, because detrital graphite is generally altered during transport, it does not exhibit the Raman spectrum of perfect graphite and instead shows defect bands with various 
Table 2. RSCM Temperature Data Obtained in Central and Southern Taiwan Along the Three Transects ${ }^{\mathrm{a}}$

\begin{tabular}{|c|c|c|c|c|c|c|c|c|c|}
\hline Sample & Rock & Longitude & Latitude & Altitude, m & $\mathrm{n}$ & R2 Ratio & $\mathrm{sdv}$ & $\mathrm{T},{ }^{\circ} \mathrm{C}$ & $1 \sigma,{ }^{\circ} \mathrm{C}$ \\
\hline \multicolumn{10}{|c|}{ Central Cross-Island Highway } \\
\hline $\mathrm{C} 02-05$ & slate & 121.0972 & 24.0066 & 1091 & 10 & $>0.7$ & & $<330$ & \\
\hline $\mathrm{C} 02-06$ & slate & 121.1134 & 24.0162 & 939 & 10 & $>0.7$ & & $<330$ & \\
\hline $\mathrm{C} 02-10$ & slate & 121.1459 & 24.0335 & 1539 & 10 & $>0.7$ & & $<330$ & \\
\hline $\mathrm{C} 02-11$ & slate & 121.1501 & 24.0493 & 1733 & 10 & $>0.7$ & & $<330$ & \\
\hline $\mathrm{C} 02-18$ & slate & 121.2138 & 24.1144 & 2635 & 10 & $>0.7$ & & $<330$ & \\
\hline $\mathrm{C} 02-26$ & slate & 121.2970 & 24.1789 & 2637 & 10 & $>0.7$ & & $<330$ & \\
\hline $\mathrm{C} 02-28$ & slate & 121.2921 & 24.2005 & 2515 & 10 & $>0.7$ & & $<330$ & \\
\hline $\mathrm{C} 02-31$ & slate & 121.2584 & 24.2157 & 1990 & 10 & $>0.7$ & & $<330$ & \\
\hline $\mathrm{C} 02-32$ & slate & 121.2453 & 24.2464 & 1957 & 10 & $>0.7$ & & $<330$ & \\
\hline $\mathrm{C} 02-33$ & slate & 121.2282 & 24.2540 & 1890 & 10 & $>0.7$ & & $<330$ & \\
\hline $\mathrm{C} 02-35$ & schist & 121.2113 & 24.2603 & 1678 & 10 & 0.63 & 0.02 & 358 & 2 \\
\hline $\mathrm{C} 02-37$ & schist & 121.2044 & 24.2526 & 1587 & 10 & 0.64 & 0.02 & 354 & 3 \\
\hline $\mathrm{C} 02-38$ & schist & 121.1949 & 24.2573 & 1585 & 10 & 0.59 & 0.04 & 380 & 6 \\
\hline $\mathrm{C} 02-42$ & schist & 121.1557 & 24.2496 & 1494 & 10 & 0.38 & 0.02 & 473 & 3 \\
\hline $\mathrm{C} 02-43$ & schist & 121.1639 & 24.2531 & 1553 & 10 & 0.45 & 0.05 & 442 & 7 \\
\hline $\mathrm{C} 02-44$ & schist & 121.1736 & 24.2562 & 1515 & 10 & 0.52 & 0.04 & 408 & 6 \\
\hline $\mathrm{C} 02-45$ & schist & 121.1894 & 24.2590 & 1575 & 10 & 0.51 & 0.04 & 415 & 5 \\
\hline $\mathrm{C} 02-50$ & slate & 121.3065 & 24.1805 & 2556 & 10 & $>0.7$ & & $<330$ & \\
\hline $\mathrm{C} 02-51$ & slate & 121.3121 & 24.1809 & 2528 & 10 & $>0.7$ & & $<330$ & \\
\hline $\mathrm{C} 02-54$ & schist & 121.3260 & 24.1893 & 2382 & 10 & 0.69 & 0.03 & 332 & 4 \\
\hline $\mathrm{C} 02-56$ & schist & 121.3353 & 24.1840 & 2315 & 10 & 0.65 & 0.02 & 350 & 2 \\
\hline $\mathrm{C} 02-62$ & schist & 121.3502 & 24.1806 & 2331 & 10 & 0.66 & 0.02 & 349 & 2 \\
\hline $\mathrm{C} 02-63$ & schist & 121.3580 & 24.1786 & 2403 & 10 & 0.66 & 0.01 & 346 & 1 \\
\hline $\mathrm{C} 02-65$ & schist & 121.3666 & 24.1780 & 2439 & 10 & 0.63 & 0.04 & 362 & 6 \\
\hline C02-69 & schist & 121.3952 & 24.1812 & 2212 & 10 & 0.63 & 0.02 & 362 & 2 \\
\hline $\mathrm{C} 02-75$ & schist & 121.4016 & 24.1882 & 1878 & 10 & 0.64 & 0.05 & 358 & 7 \\
\hline $\mathrm{C} 02-76$ & schist & 121.4114 & 24.1950 & 1784 & 10 & 0.62 & 0.01 & 364 & 2 \\
\hline $\mathrm{C} 02-77$ & schist & 121.4131 & 24.2044 & 1603 & 10 & 0.60 & 0.01 & 373 & 2 \\
\hline $\mathrm{C} 02-78$ & schist & 121.4153 & 24.2073 & 1432 & 12 & 0.57 & 0.05 & 386 & 6 \\
\hline $\mathrm{C} 02-79$ & schist & 121.4527 & 24.2035 & 1091 & 15 & 0.43 & 0.05 & 449 & 5 \\
\hline C02-81 & schist & 121.4682 & 24.1960 & 1023 & 10 & 0.33 & 0.02 & 492 & 3 \\
\hline $\mathrm{C} 02-82$ & schist & 121.4750 & 24.1907 & 789 & 10 & 0.32 & 0.06 & 500 & 9 \\
\hline $\mathrm{C} 02-84$ & schist & 121.4755 & 24.2147 & 761 & 11 & 0.28 & 0.06 & 516 & 8 \\
\hline $\mathrm{C} 02-85$ & schist & 121.4904 & 24.1739 & 448 & 12 & 0.34 & 0.06 & 488 & 8 \\
\hline C04-14 & schist & 121.0996 & 24.2441 & 1178 & 10 & 0.50 & 0.05 & 417 & 7 \\
\hline C04-15 & schist & 121.0996 & 24.2441 & 1178 & 10 & 0.58 & 0.02 & 385 & 3 \\
\hline C04-16 & schist & 121.0978 & 24.2453 & 1178 & 10 & 0.66 & 0.04 & 345 & 6 \\
\hline C04-18 & schist & 121.0909 & 24.2515 & 1039 & 10 & 0.67 & 0.04 & 341 & 5 \\
\hline C04-20 & schist & 121.0806 & 24.2398 & 984 & 10 & 0.64 & 0.05 & 355 & 7 \\
\hline C04-21 & schist & 121.0736 & 24.2391 & 978 & 10 & 0.70 & 0.04 & 329 & 6 \\
\hline $\mathrm{C} 04-22$ & schist & 121.0619 & 24.2293 & 1080 & 10 & 0.65 & 0.01 & 353 & 2 \\
\hline C04-24 & schist & 121.0500 & 24.2305 & 1087 & 13 & 0.67 & 0.07 & 343 & 9 \\
\hline $\mathrm{C} 04-26$ & schist & 121.0334 & 24.2208 & 985 & 10 & 0.63 & 0.02 & 361 & 2 \\
\hline C04-28 & schist & 121.0254 & 24.2124 & 916 & 10 & 0.64 & 0.03 & 356 & 5 \\
\hline C04-29 & slate & 121.0063 & 24.2117 & 825 & 10 & $>0.7$ & & $<330$ & \\
\hline $\mathrm{C} 04-32$ & slate & 121.2961 & 24.1800 & 2632 & 9 & $>0.7$ & & $<330$ & \\
\hline $\mathrm{C} 04-35$ & schist & 121.1547 & 24.2502 & 1374 & 10 & 0.37 & 0.04 & 475 & 6 \\
\hline $\mathrm{C} 04-37$ & schist & 121.2011 & 24.2567 & 1547 & 10 & 0.64 & 0.03 & 354 & 4 \\
\hline C04-45 & schist & 121.4529 & 24.2001 & 1132 & 10 & 0.37 & 0.03 & 478 & 7 \\
\hline $\mathrm{C} 04-46$ & schist & 121.4674 & 24.1972 & 1142 & 10 & 0.33 & 0.05 & 496 & 8 \\
\hline C04-48 & schist & 121.4783 & 24.2089 & 827 & 12 & 0.33 & 0.05 & 496 & 6 \\
\hline C04-49 & schist & 121.4838 & 24.1973 & 629 & 10 & 0.30 & 0.05 & 505 & 7 \\
\hline C04-52 & schist & & & 404 & 10 & 0.32 & 0.02 & 497 & 3 \\
\hline yg04-b & schist & 121.3733 & 24.1911 & & 10 & 0.62 & 0.03 & 364 & 4 \\
\hline yg04-c & schist & 121.4222 & 24.2148 & & 11 & 0.49 & 0.03 & 422 & 4 \\
\hline yg04-d & schist & 121.4271 & 24.2085 & & 9 & 0.44 & 0.11 & 443 & 16 \\
\hline yg04-e & schist & 121.4321 & 24.2075 & & 11 & 0.47 & 0.05 & 431 & 7 \\
\hline yg04-f & schist & 121.4526 & 24.2063 & & 10 & 0.38 & 0.05 & 474 & 7 \\
\hline yg04-g & schist & 121.4607 & 24.2020 & & 10 & 0.33 & 0.05 & 496 & 8 \\
\hline \multicolumn{10}{|c|}{ Southern Cross-Island Highway } \\
\hline S02-06 & schist & 121.0546 & 22.9023 & 351 & 10 & 0.64 & 0.05 & 354 & 6 \\
\hline S02-09 & schist & 121.1675 & 23.1149 & 311 & 10 & 0.60 & 0.04 & 372 & 5 \\
\hline S02-11 & schist & 121.1368 & 23.1338 & 400 & 10 & 0.39 & 0.04 & 469 & 6 \\
\hline $\mathrm{S} 02-12$ & schist & 121.1219 & 23.1365 & 421 & 10 & 0.37 & 0.02 & 474 & 3 \\
\hline $\mathrm{S} 02-14$ & schist & 121.0853 & 23.1415 & 449 & 10 & 0.33 & 0.04 & 493 & 5 \\
\hline $\mathrm{S} 02-15$ & schist & 121.0709 & 23.1431 & 552 & 10 & 0.40 & 0.03 & 463 & 4 \\
\hline S02-18 & schist & 121.0425 & 23.1634 & 791 & 10 & 0.41 & 0.02 & 457 & 3 \\
\hline
\end{tabular}


Table 2. (continued)

\begin{tabular}{|c|c|c|c|c|c|c|c|c|c|}
\hline Sample & Rock & Longitude & Latitude & Altitude, $\mathrm{m}$ & $\mathrm{n}$ & R2 Ratio & $\mathrm{sdv}$ & $\mathrm{T},{ }^{\circ} \mathrm{C}$ & $1 \sigma,{ }^{\circ} \mathrm{C}$ \\
\hline S02-20 & schist & 121.0145 & 23.1791 & 804 & 10 & 0.46 & 0.04 & 436 & 6 \\
\hline $\mathrm{S} 02-23$ & schist & 121.0237 & 23.1832 & 1006 & 10 & 0.43 & 0.02 & 451 & 3 \\
\hline S02-24 & schist & 121.0128 & 23.1894 & 1069 & 10 & 0.43 & 0.02 & 449 & 4 \\
\hline S02-25 & schist & 120.9947 & 23.1996 & 1366 & 10 & 0.44 & 0.03 & 447 & 4 \\
\hline S02-26 & schist & 121.0186 & 23.2021 & 1573 & 10 & 0.43 & 0.03 & 447 & 5 \\
\hline S02-28 & schist & 121.0165 & 23.2109 & 1696 & 10 & 0.45 & 0.02 & 442 & 3 \\
\hline S02-29 & schist & 121.0063 & 23.2223 & 1810 & 10 & 0.54 & 0.04 & 400 & 6 \\
\hline S02-31 & schist & 120.9901 & 23.2437 & 2015 & 10 & 0.62 & 0.02 & 367 & 2 \\
\hline $\mathrm{S} 02-33$ & schist & 120.9717 & 23.2474 & 2379 & 10 & 0.67 & 0.03 & 345 & 4 \\
\hline $\mathrm{S} 02-37$ & slate & 120.9422 & 23.2660 & 2725 & 10 & $>0.7$ & & $<330$ & \\
\hline $\mathrm{S} 02-43$ & slate & 120.9105 & 23.2847 & 2136 & 5 & $>0.7$ & & $<330$ & \\
\hline S04-03 & schist & 121.0114 & 23.1845 & 794 & 10 & 0.48 & 0.04 & 428 & 5 \\
\hline S04-04 & schist & 121.0153 & 23.2129 & 1725 & 11 & 0.44 & 0.04 & 447 & 6 \\
\hline S04-05 & schist & 121.0040 & 23.2227 & 1822 & 10 & 0.51 & 0.04 & 408 & 5 \\
\hline S04-06 & schist & 121.0006 & 23.2274 & 1933 & 10 & 0.56 & 0.03 & 390 & 4 \\
\hline Y04-06 & schist & & & 341 & 10 & 0.49 & 0.06 & 422 & 8 \\
\hline \multicolumn{10}{|c|}{ Mid-Taiwan Highway } \\
\hline H04-01 & schist & 121.0024 & 23.7895 & & 10 & 0.61 & 0.02 & 370 & 3 \\
\hline H04-03 & schist & 120.9877 & 23.7959 & 661 & 10 & 0.65 & 0.03 & 352 & 4 \\
\hline H04-04 & schist & 120.9835 & 23.8027 & 581 & 10 & 0.63 & 0.03 & 359 & 4 \\
\hline H04-05 & schist & 120.9764 & 23.8020 & 584 & 10 & 0.64 & 0.03 & 358 & 4 \\
\hline H04-06 & schist & 120.9695 & 23.7980 & 505 & 10 & 0.66 & 0.05 & 347 & 8 \\
\hline H04-07 & schist & 120.9606 & 23.7958 & 467 & 10 & 0.64 & 0.03 & 354 & 4 \\
\hline H04-10 & slate & 120.8990 & 23.7909 & 394 & 5 & $>0.7$ & & $<330$ & \\
\hline
\end{tabular}

${ }^{\mathrm{a}}$ Three transects are central, mid, and southern highways. For each sample, we provide: rock lithology, sample position (WGS84 system), altitude in m (italic indicates that it is retrieved from the 40 m-DEM of Taiwan), number of spectra (n), mean R2 ratio for $n$ spectra with corresponding standard deviation $(\mathrm{sdv})$, and calculated temperature with standard error $(1-\sigma)$. Standard error is the standard deviation divided by $\sqrt{n}$. The absolute error on temperature is $\pm 50^{\circ} \mathrm{C}$ [Beyssac et al., 2002a].

intensities. R2 ratios and T estimates based on 10 spectra in these samples generally show unusual very large uncertainties that make them easily recognizable. In order to avoid any bias due to the presence of detrital graphite, we do not present here the results obtained from RSCM within the Tachien sandstone (core of the HR units). Obtained RSCM peak $\mathrm{T}$ are reported in Table 2 .

\section{3. (U-Th)/He Methods}

[23] Zircon grains were separated from sandstones and gneisses using standard magnetic and heavy liquid techniques. Analyses were performed at the GPS division of Caltech (Pasadena, California, USA). Grains to be dated were selected to be as large as possible (typically 2550 microns radius) and to be euhedral. Individual grains were loaded in small $\mathrm{Pt}$ tubes and heated in-vacuum to $1300^{\circ} \mathrm{C}$ for $20 \mathrm{~min}$. The evolved $\mathrm{He}$ was analyzed by isotope dilution quadrupole mass spectrometry. Each grain was heated a second time and the evolved gas analyzed to ensure complete He extraction. Typical helium blanks of $\sim 5 \times 10^{-17}$ mol were negligible $(<1 \%)$ compared with the He derived from the zircons. The grains were then flux melted in $\mathrm{Li}$ metaborate in a $1200^{\circ} \mathrm{C}$ muffle furnace. The resulting glass was dissolved in nitric acid, which was then spiked with ${ }^{235} \mathrm{U}$ and ${ }^{230} \mathrm{Th}$, and analyzed on a Finnigan Element inductively coupled plasma mass spectrometer. $\mathrm{U}$ blanks were typically a few percent of the measured signal and never exceeded $7 \%$. Th blanks were about a factor of 2 higher, but because Th contributes to so little helium to these zircons (usually $<20 \%$ ), uncertainties in this correction are not particularly significant. Grain dimensions were used to compute $\alpha$ ejection correction $\left(\mathrm{F}_{\mathrm{T}}\right)$ values. The propagated analytical uncertainty on these ages is typically of 5\% (1-sigma), primarily arising from uncertainty in the ejection correction. Ages were obtained from 2 to 6 individual grains.

[24] Obtained (U-Th)/He ages are reported in Table 3. In this study, most of the (U-Th)/He ages were obtained on detrital zircons from Eocene to Miocene sandstones. Because these zircons have most likely undergone a complex polymetamorphic history prior to the late Cenozoic collision, it is important to distinguish ages inherited from a previous thermal history (partially reset or detrital ages) and those reflecting cooling subsequent to burial and heating during the collision (reset age). A fully reset age implies that the T was high enough during the most recent event to reset the thermochronological age, which should then be lower than the stratigraphic age of the sediment. In Table 3, a mean age for $n$ replicates was calculated when all replicates are reset, and this age is reported with a 1-sigma standard error.

\section{Thermometric and Thermochronological Results Along the Central Highway (Northern Transect)}

\subsection{Overview}

[25] The central cross-island highway is the northernmost studied section and in the following will be referred to as the 


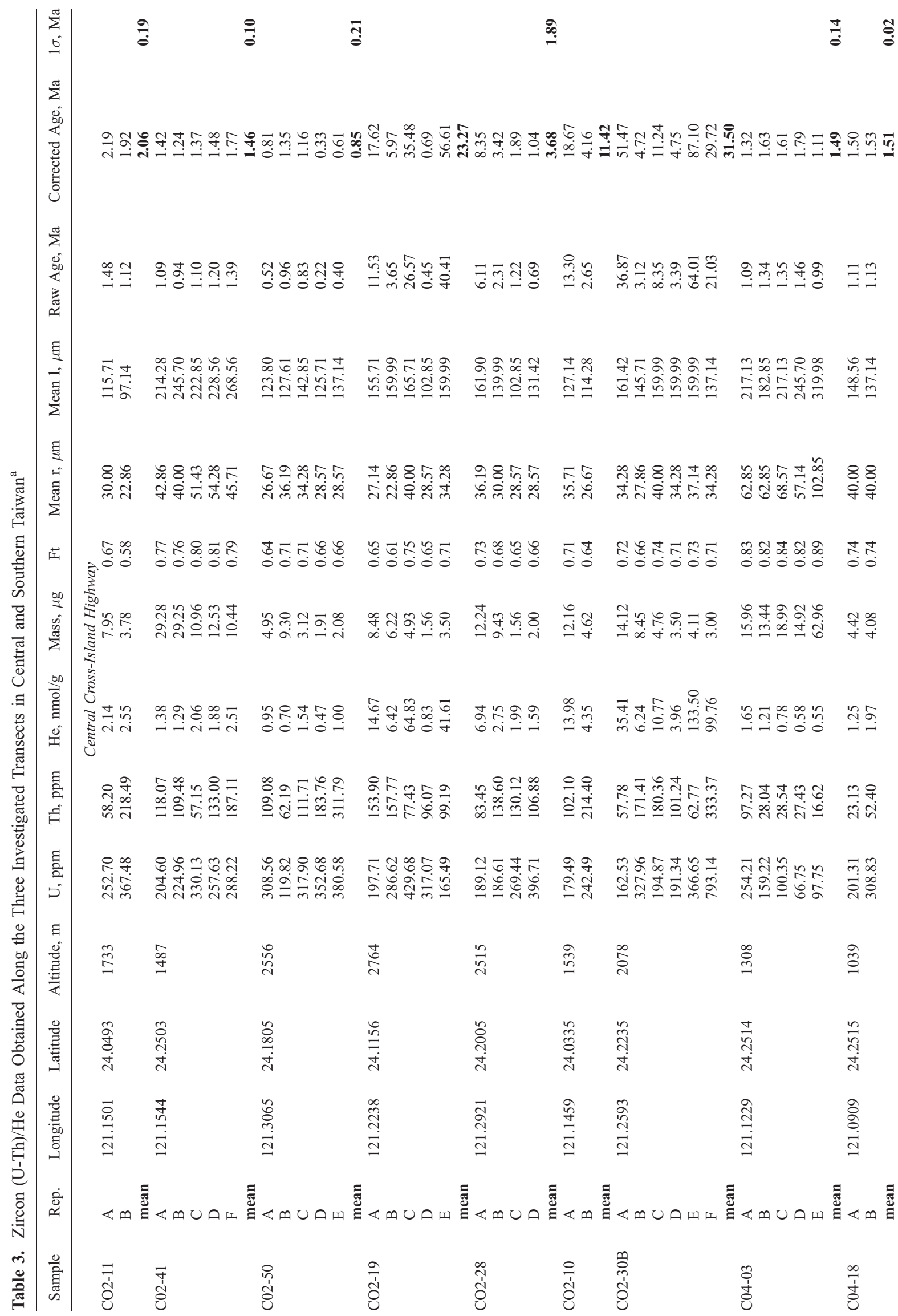




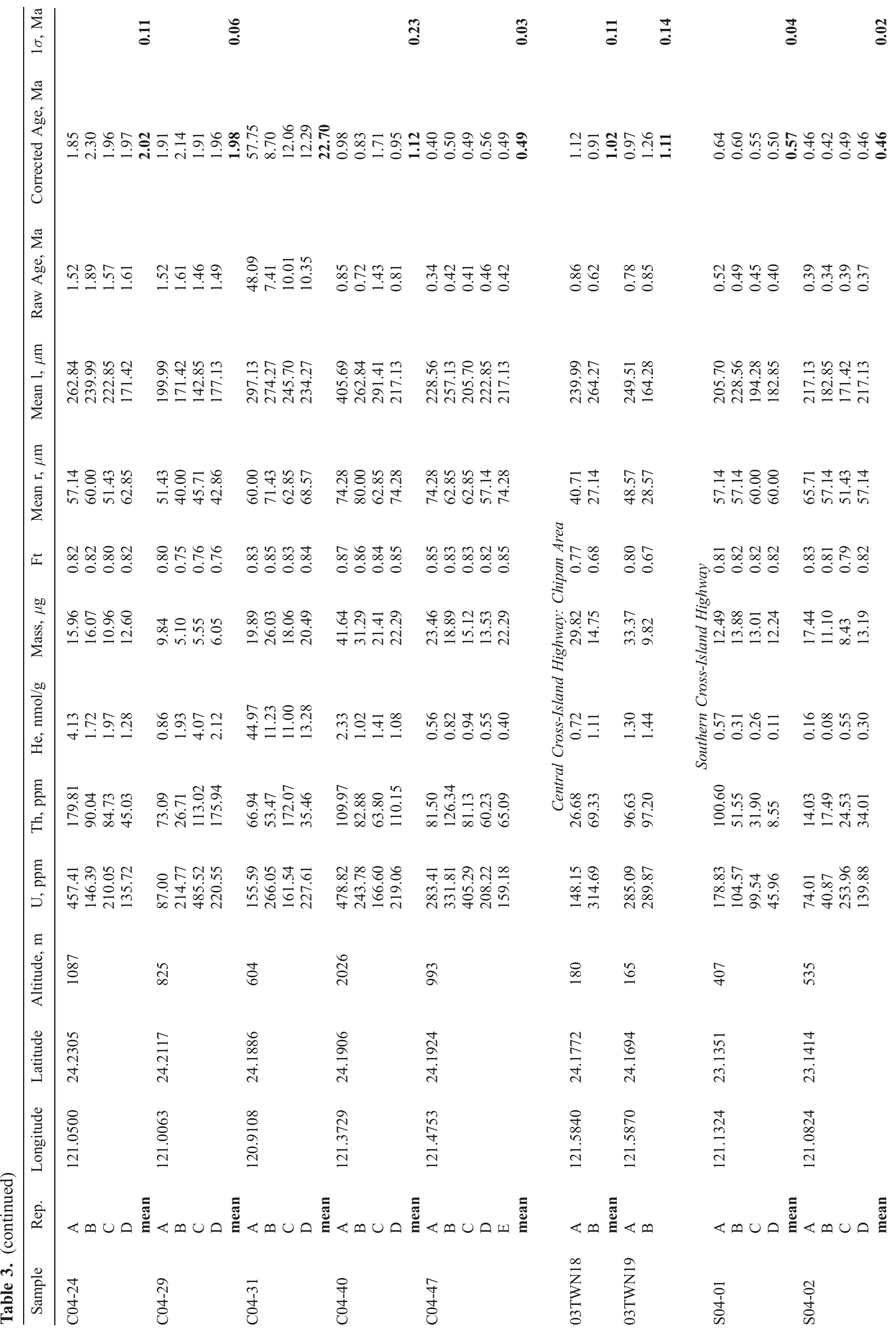




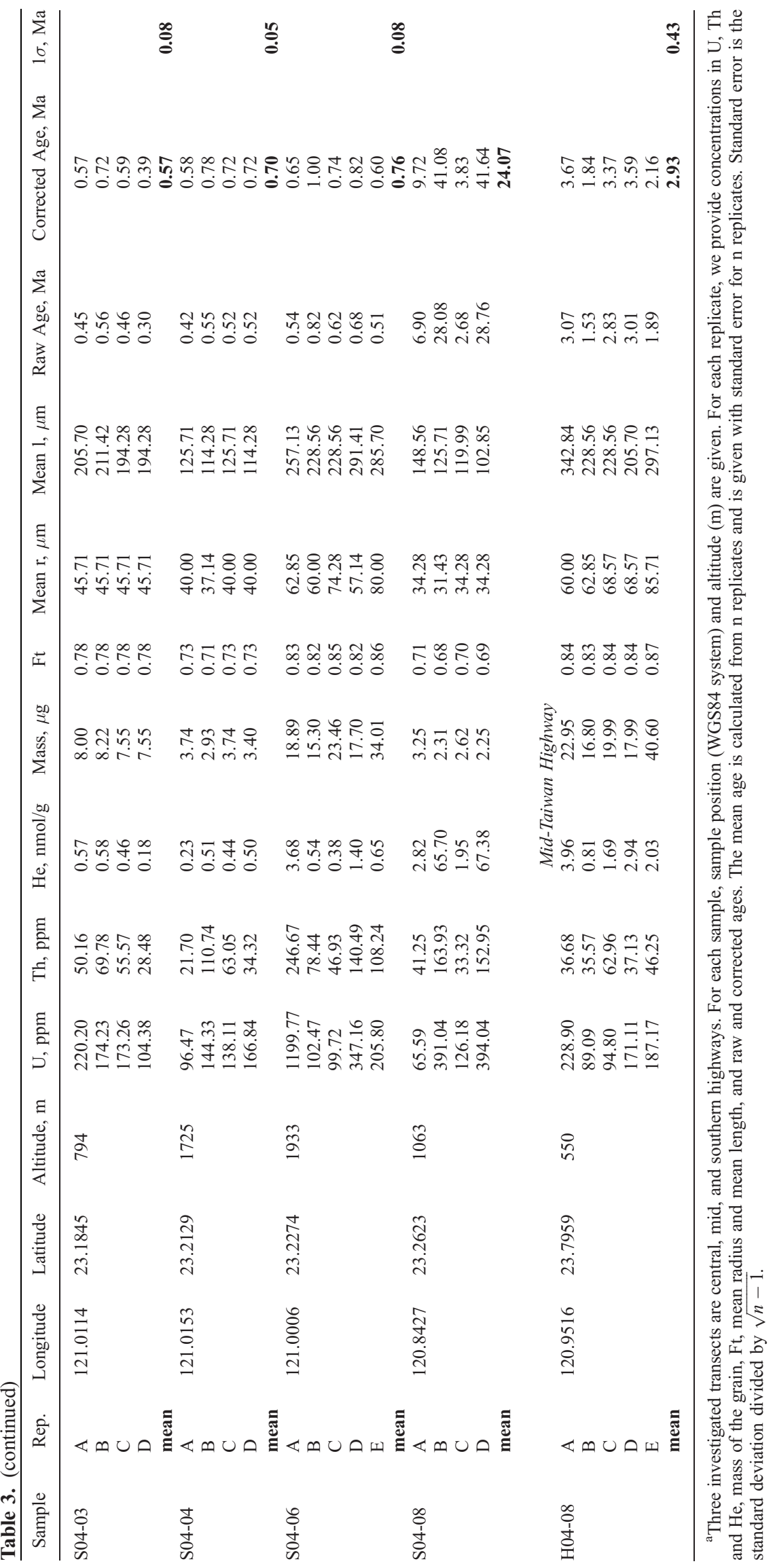




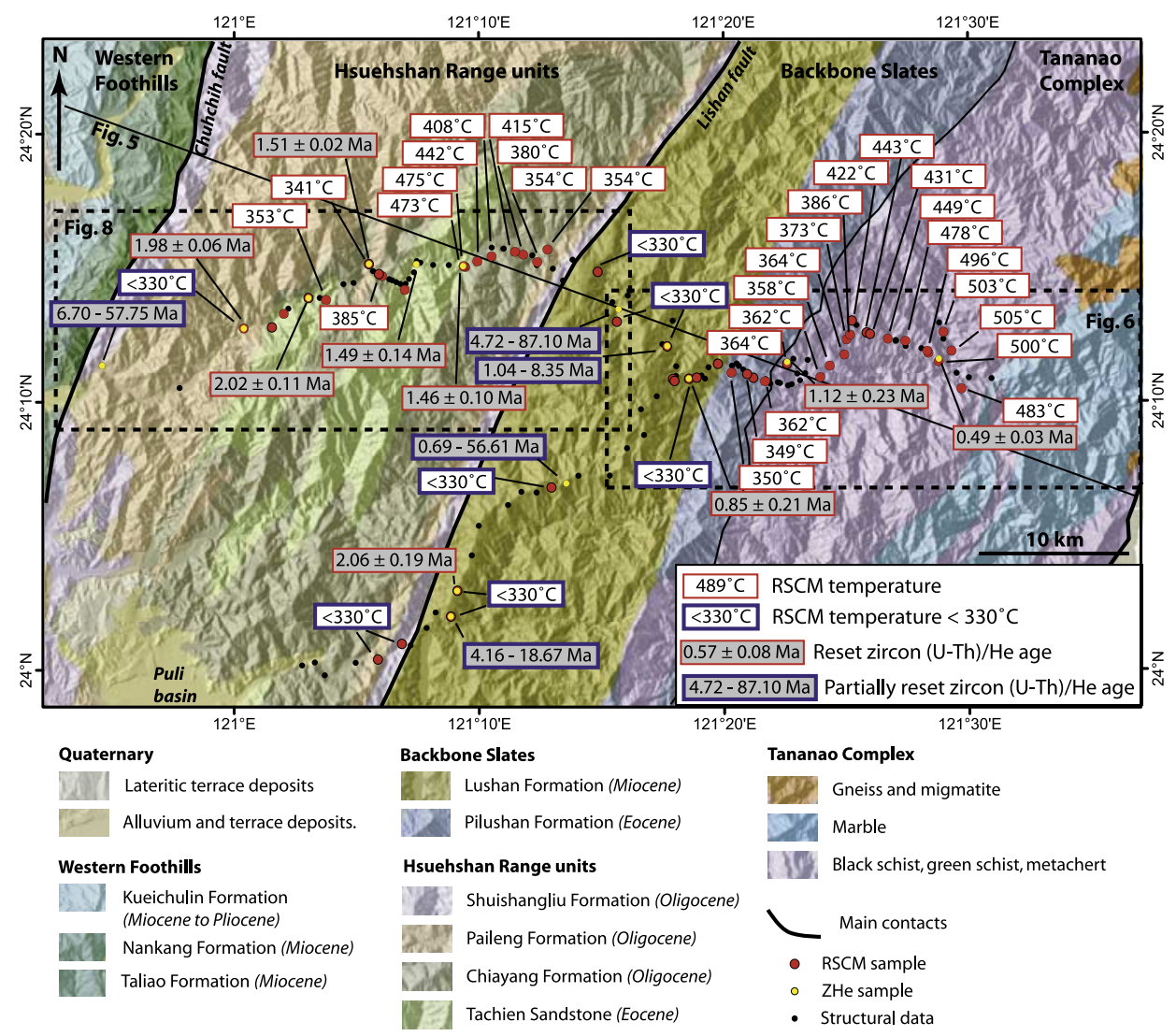

Figure 4. Geological map of central Taiwan in the vicinity of the central cross-island highway and of the Puli road (see Figure 1 for location). The main three structural units are, from W to E: Hsuehshan Range units, Backbone slates, and Tananao complex. Mean RSCM temperatures (Table 2) and zircon $(\mathrm{U}-\mathrm{Th}) / \mathrm{He}$ ages (Table 3) obtained in this study are shown. Minimum and maximum zircon (U-Th)/He ages are given for each partially reset sample (see Table 3). Boxes locate Figures 6 and 8.

northern profile (Figure 1). This road offers a section through the most mature part of the Taiwan mountain belt with respect to the southward propagation of the collision and with account on the more exhumed HR units along this section (Figure 1). At the stage of this section, structures are not yet affected by the reversal of subduction farther northeast [Suppe, 1984] (Figure 1). Our samples come from the cross-island highway, from Tungshih to Tailuko, and from along the Puli to Tayuling road (Figure 1). On Figure 4, we have represented the RSCM and $\mathrm{ZHe}$ results on the geological map. On Figure 5, these data as well as a compilation of previous thermochronological constraints from the literature (Tables S1 and S2) are projected onto a N110 transect as a function of distance from the LV.

\subsection{Pre-Tertiary Basement: Tananao Complex \\ 4.2.1. Structural Background}

[26] Along our northern profile, the section crosses the Tailuko Belt of the TC, but not the Yuli Belt located farther south (Figure 1). In Figure 6, we present a summary of the stratigraphic, structural, petrologic and geochronologic data available along this section, including our results and the data from the literature. The stratigraphic background is a first-order attempt proposed by Ernst [1983] and has been slightly modified according to our own field observations. In Figure 6, we present our own structural measurements that mostly consist of the main foliation $\mathrm{S} 1$ and occasionally of bedding S0. The dominant foliation is generally parallel to bedding, especially in the schists. At a larger scale, the western part of the TC generally exhibits a relatively simple structural pattern with E-dipping bedding/foliation, and gets more complex eastward where several successive deformation stages are observed. Our own measurements are in good agreement with those performed by Crespi et al. [1996] and Pulver et al. [2002]. We mention here the mean values for the orientation of schistosity given by Pulver et al. [2002], and present their results from W to E (Figure 6). A first domain (domain III of Pulver et al. [2002]) encompasses the Pilushan Formation and westernmost TC with a relatively constant S1 (N024E, 68SE) and a nearly downdip L1. The second domain (domain IIb) extending approximately between the first thick layer of pelitic schists to the $\mathrm{W}$ and the town of Loshao to the E is characterized by a steep to nearly vertical S1 schistosity that forms a cleavage fan. In 


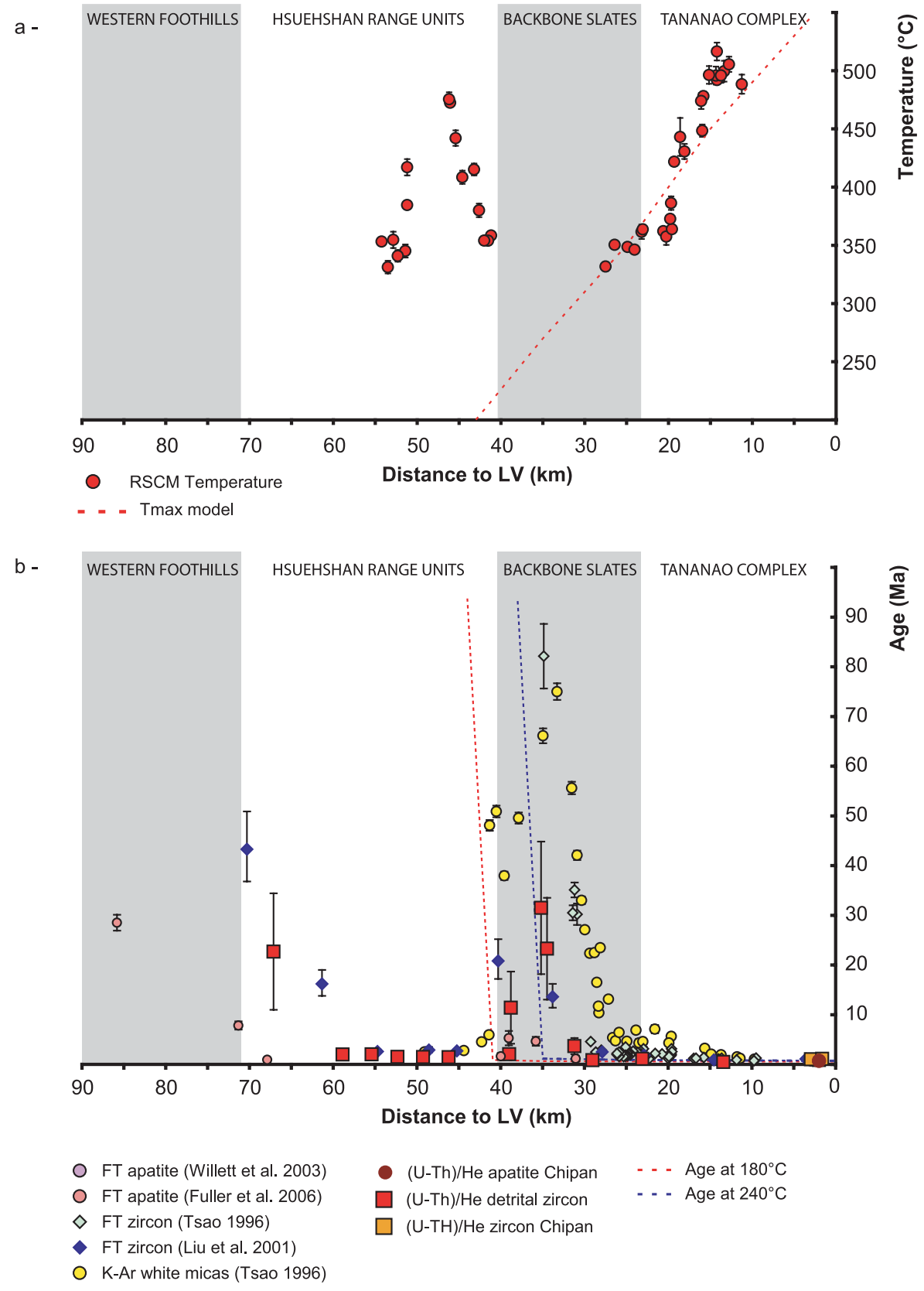

Figure 5. (RSCM temperatures and thermochronologic data projected on a N110 profile from the WF (W) to the LV (E). See Figure 4 for location. RSCM temperatures and zircon (U-Th)/He ages are represented on Figure 4. The horizontal axis indicates the horizontal distance to the LV along this transect. (a) RSCM temperatures obtained in this study (mean value with 1- $\sigma$ standard error). Red dashed line reports the predictions of the model of Barr et al. [1991] that assumes 25\% of constant underplating below the wedge. The absolute uncertainty on RSCM temperature is $\pm 50^{\circ} \mathrm{C}$. (b) Thermochronologic data: $(\mathrm{U}-\mathrm{Th}) / \mathrm{He}$ on apatite and zircon in the Chipan gneiss (this study, Table 3), (U-Th)/He on detrital zircon (this study, Table 3), zircon fission tracks [Tsao, 1996] ( $\chi 2$ ages from Liu et al. [2001] (Table S1)), apatite fission tracks [Willett et al., 2003; Fuller et al., 2006] and K-Ar ages on white mica clay fractions [Tsao, 1996] (Table S2). Red and blue dashed lines report the predictions in terms of $\mathrm{ZHe}\left(180^{\circ} \mathrm{C}\right.$ closure temperature) and ZFT $\left(240^{\circ} \mathrm{C}\right.$ closure temperature) ages respectively of the model of Barr et al. [1991] that assumes $25 \%$ of constant underplating below the wedge. 


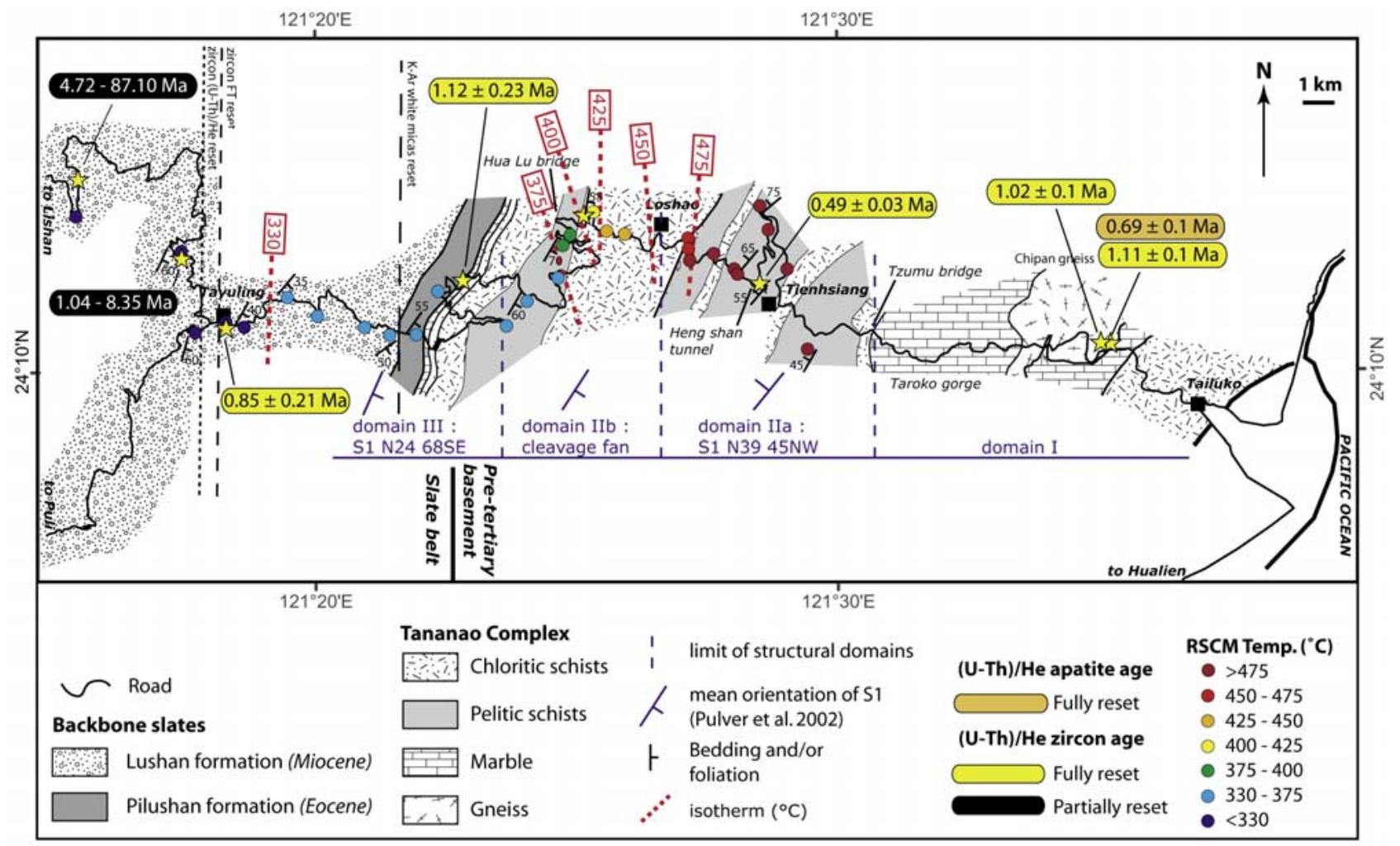

Figure 6. Geological map of the eastern BS and TC along the central cross-island highway, modified from Ernst [1983] (see Figure 1 and 4 for location). The structural framework has been simplified using the domains defined by Pulver et al. [2002] and by assuming the mean foliation in each domain. RSCM temperatures obtained in this region (blue to red circles) were used to determine the position of the isotherms for peak metamorphic temperatures. zircon (U-Th)/He ages from this study are shown. Minimum and maximum zircon (U-Th)/He ages are given for each partially reset sample (see Table 3). The positions of the limit for resetting of ZHe, ZFT, and K-Ar on white micas shown on Figure 7 are represented here by the different black dashed lines.

this domain the main L1 lineation plunges moderately toward the S-SW. In Loshao, the orientation of S1 shallows to a moderate dip toward the NW with a mean orientation of N39E, $45 \mathrm{NW}$ and a gently plunging L1 to the SW (domain IIa). The last domain starts at the boundary between the schists and the marbles in the Taroko gorge close to the Tzumu Bridge. This domain (domain I) is characterized by a complex inherited deformation pattern, and defines with domain IIa a broad anticline in S1 with a core of marbles locally intruded by the Chipan gneiss during the late Cretaceous [Lo and Onstott, 1995].

\subsubsection{RSCM and Thermochronological Results}

[27] We have carried out systematic petrologic observations along these sections that confirm the general metamorphic pattern proposed by Ernst [1983] which is (1) the presence of biotite within the TC, from green color to the $\mathrm{W}$ to red-brown to the $\mathrm{E},(2)$ the presence of epidotes and white micas and (3) the decrease and disappearance eastward of $\mathrm{CM}$ content within the metapelites that limits our RSCM investigations to the pelitic schists outcropping westward from the thick marble series of the Taroko gorge. Both
RSCM T and thermochronologic data for the TC along this section are shown on the projected profile of Figure 7. More than 20 RSCM samples were analyzed with T ranging from $350^{\circ} \mathrm{C}$ up to $500^{\circ} \mathrm{C}$. As shown in Figures 6 and 7, the lowest $\mathrm{T}$ are of $\sim 350^{\circ}-370^{\circ} \mathrm{C}$ in the westernmost portion of the TC at the contact with the Pilushan Formation (BS). A few kilometers before Loshao (Hua-Lu bridge), T starts to increase progressively eastward from $370^{\circ} \mathrm{C}$ up to nearly $500^{\circ} \mathrm{C}$ at the Heng-Shan tunnel a few $\mathrm{km}$ after Loshao. We attempted to document as best as possible this portion of the transect, but owing to sparse exposure and CM-lacking chloritic schists we were not able to continuously sample through the whole area. Because the BS and western TC series were observed to be overturned [Suppe, 1976; Ernst, 1983], this gradient is inverted as T increases upward within the stratigraphic section. This inverted thermal gradient coincides quite well with the cleavage fan documented by Pulver et al. [2002] (domain IIb). If we take the average structural orientation provided by Pulver et al. [2002], we can estimate from RSCM data a rough thermal gradient of $15^{\circ}-20^{\circ} \mathrm{C} / \mathrm{km}$. Around Tienhsiang in the eastern part of the 
a -

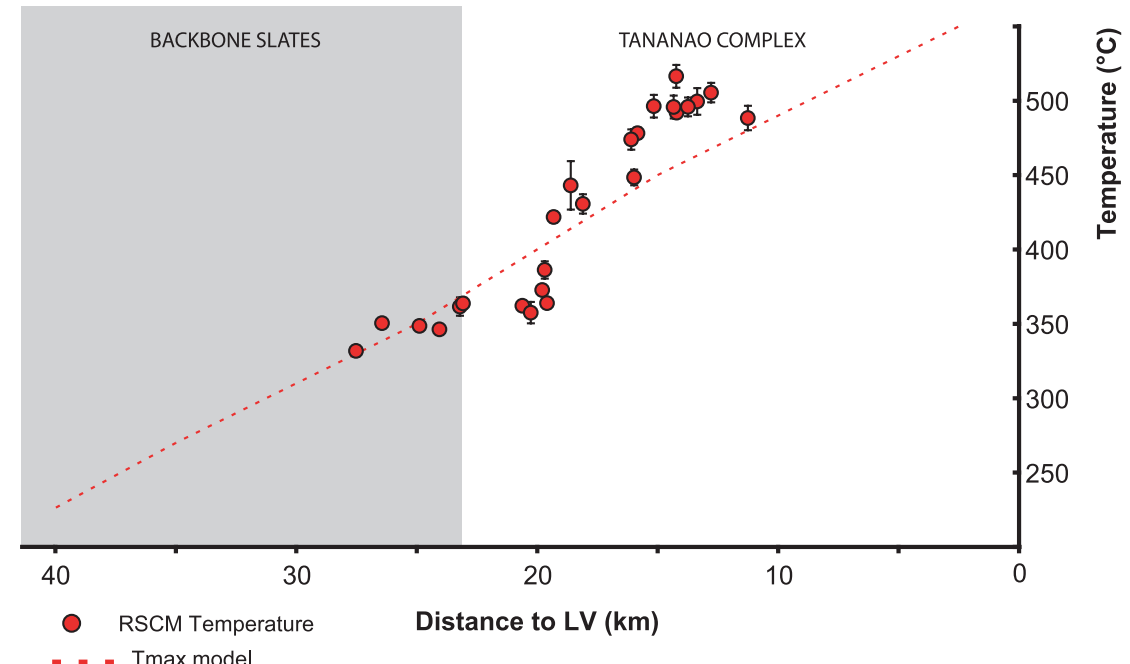

$b-$

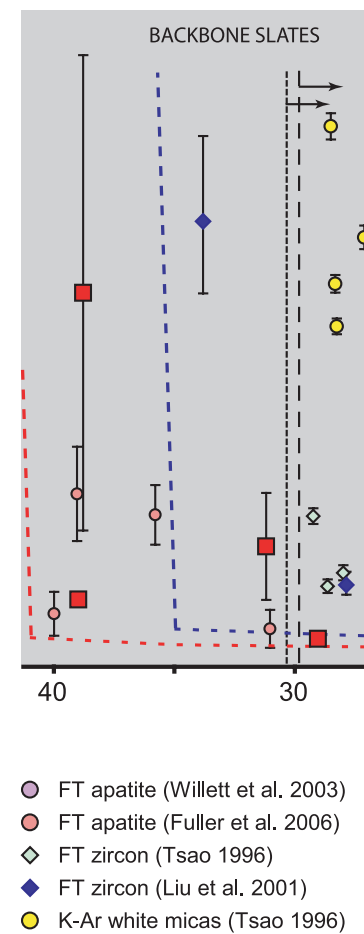

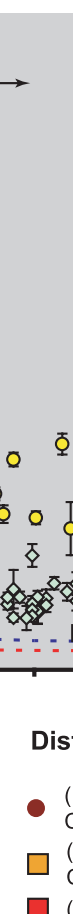

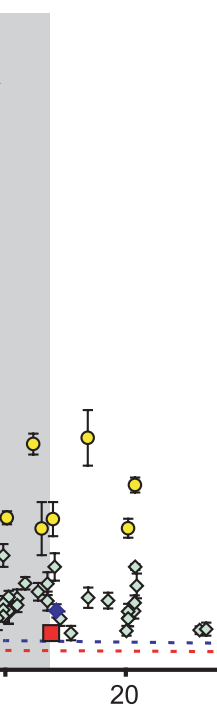

TANANAO COMPLEX

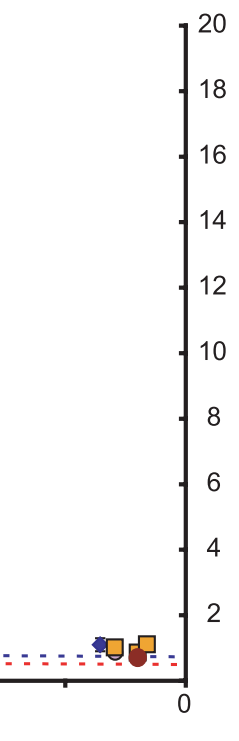

Distance to LV (km)

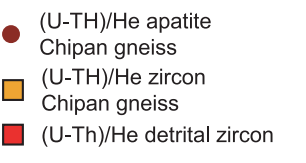

- - Age at $180^{\circ} \mathrm{C}$

- - K-Ar resetting

- - Z ZFT resetting

-...... ZHe resetting
- - Age at $240^{\circ} \mathrm{C}$

Figure 7. Expansion of Figure 5 in the Tananao complex and Backbone slates. (a) RSCM temperatures and predictions of the model of Barr et al. [1991] that assumes $25 \%$ of constant underplating below the wedge (red dashed line). The absolute uncertainty on RSCM temperature is $\pm 50^{\circ} \mathrm{C}$. (b) Thermochronologic data in the eastern BS and TC along the central cross-island highway (zoom from Figure 5b). Thermochronologic data: (U-Th)/He on apatite and zircon in the Chipan gneiss (this study, Table 3), (U-Th)/He on detrital (this study, Table 3), zircon fission tracks [Tsao, 1996] ( $\chi 2$ ages from Liu et al. [2001] (Table S1)), apatite fission tracks [Willett et al., 2003; Fuller et al., 2006] and K-Ar on white mica clay fractions [Tsao, 1996] (Table S2). Red and blue dashed lines report the predictions in terms of ZHe $\left(180^{\circ} \mathrm{C}\right.$ closure temperature $)$ and $\mathrm{ZFT}\left(240^{\circ} \mathrm{C}\right.$ closure temperature) ages respectively of the model of Barr et al. [1991] that assumes 25\% of constant underplating below the wedge. 
TC schists, between the Heng-shan Tunnel and Tienhsiang, where schistosity forms an anticlinorium, $\mathrm{T}$ remains constant around $500^{\circ} \mathrm{C}$.

[28] Five $\mathrm{ZHe}$ ages have been obtained in the TC, two of them come from detrital zircons in metasandstones interbedded with the pelitic schists, and the three others were sampled from the Chipan gneiss. The youngest age $(0.49 \pm$ $0.03 \mathrm{Ma}$ ) was obtained from a metasandstone sampled in the schists near Tienhsiang where RSCM T are high $\left(500^{\circ} \mathrm{C}\right)$ (Figure 6). In the case of the four other samples, from the western sandstone and the Chipan gneiss, ZHe thermochronology yielded ages slightly older, $1.12 \pm 0.23 \mathrm{Ma}$ and $0.86 \pm$ 0.1 to $1.02 \pm 0.1$ Ma respectively (Figure 6). On Figure $7 \mathrm{~b}$ we have projected these ages together with apatite fission track (AFT) [Willett et al., 2003; Fuller et al., 2006], ZFT [Tsao, 1996; Liu et al., 2001; Willett et al., 2003] and K-Ar ages on the clay fraction $(<2 \mu \mathrm{m})$ of white micas [Tsao, 1996]. A general good agreement between these different independent results is observed. For instance, the ZFT data obtained by Liu et al. [2001] are consistent with the large data set from Tsao [1996], without any major differences between central/ pooled and $\chi^{2}$ ages. More generally, we observe a systematic younging of the ages from $\mathrm{K}$-Ar white mica ages to ZFT and finally to ZHe ages in agreement with the closure T for the different systems assumed in the source papers $\left(\sim 350^{\circ} \mathrm{C}, 240^{\circ} \mathrm{C}\right.$ and $180^{\circ} \mathrm{C}$, respectively). All data except $\mathrm{ZHe}$ ages show westward increasing ages within the TC, from the contact with the Taroko marbles to the one with the slate belt. All ages are very young with typical values of ZFT and K-Ar ages in the range of $0.75-1.25 \mathrm{Ma}$ and $1.00-1.20 \mathrm{Ma}$ respectively to the $\mathrm{E}$, and 1.6-3.5 Ma and 4.3-7.0 Ma respectively to the W. This gradient in ages is consistent with the trend depicted for RSCM T: high RSCM $\mathrm{T}$ correspond to young thermochronologic ages (Figure 7).

\subsection{Backbone Slates}

\subsubsection{Structural Background}

[29] Along our northern profile, the BS has been studied from Lishan to Tayuling along the central cross-island highway and from Puli to Tayuling farther south. Because the road from Tayuling to Lishan is severely affected by landsliding, our structural observations are more reliable on the transect from Puli to Tayuling. In general, the Lushan Formation shows a monoclinal E-dipping bedding affected by little brittle deformation whereas the easternmost Lushan and Pilushan Formations exhibit penetrative ductile deformation with an E-dipping S1 schistosity and consistent topto-the-W sense of shear.

\subsubsection{RSCM and Thermochronological Results}

[30] RSCM thermometry has been systematically applied along both road sections and all the $\mathrm{T}$ obtained in the Lushan Formation are below the lower limit of applicability of the method $\left(330^{\circ} \mathrm{C}\right)$, except to the east below the Pilushan Formation. In this area, RSCM thermometry yielded $\mathrm{T}$ in the range of $340^{\circ}-360^{\circ} \mathrm{C}$ in the eastern Lushan and overlying Pilushan Formations, in continuity with those estimated in the adjacent TC, suggesting that there is no significant metamorphic break across the contact between the TC and the slate belt. Several ZHe ages were measured in the Lushan Formation within sandstone beds. All but two samples (C02-11 and CO2-50; Table 3) are partially reset. One of the two fully reset samples was collected close to the contact with the HR units along the Puli to Tayuling road, and yielded a mean age of $2.06 \pm 0.19 \mathrm{Ma}$ on only two replicates (Figures 4 and 5). The other one was taken close to the Pilushan Formation to the east (Figure 6) from a sandstone bed. It yielded an age in the same range as those obtained in western TC (sample C02-50 - 0.85 $\pm 0.21 \mathrm{Ma}$ ). Similarly, ZFT ages within the eastern BS are in the range 2.40-4.60 Ma, and K-Ar ages on white micas are in the range 4.30-7.00 Ma (Figure 7) [Tsao, 1996; Liu et al., 2001]. More generally, all the thermochronologic data available in the rest of Lushan Formation, except for the easternmost area suggest that most of this Formation underwent a very low thermal episode that did not reset any of the thermochronometers (Figures 5 and 7). Metamorphism and exhumation have therefore been minor within most of the $\mathrm{BS}$, with maximum $\mathrm{T}$ most probably not exceeding $200^{\circ} \mathrm{C}$, except in the easternmost BS close to the TC.

\subsection{Hsuehshan Range Units}

\subsubsection{Structural Background}

[31] The northern profile offers the most complete section through the HR units. On Figure 8, we display the main structural information from the literature together with our RSCM T and ZHe ages. Along this profile, the HR units are composed of a duplicate anticline system in which the stratigraphic core is Eocene Tachien sandstone and the youngest units are Oligocene in age (Shuichangliu Formation). The inner anticline, namely the Tachien anticline, is composed of the Oligocene Chiayang Formation comformably overlying the Tachien sandstone. The Chiayang Formation is characterized by a steep eastward dipping foliation and has been affected by coaxial deformation [Clark et al., 1993; Tillman and Byrne, 1995]. Microstructures associated with this deformation have been studied in detail by these authors who have shown an increasing elongation in the foliation plane down-section within the Chaiyang Formation. Deformation within the Tachien sandstone is more challenging to characterize because of the lithology. However, the black slaty beds within the sandstones emphasize remarkably the anticlinal structure in the landscape. An E-dipping thrust marks the contact between the two anticlines [Tillman and Byrne, 1995] which is not localized at the stratigraphic boundary between the Tachien sandstone within the eastern structure and the underlying Chaiyang Formation of the western anticline (Figure 8). The western anticline is less developed than the inner (easternmost) one, with a thinner Chaiyang Formation and still a core of Eocene Tachien sandstone. Interestingly, the Chaiyang Formation still exhibits an increasing gradient of elongation going downsection toward the sandstone [Tillman and Byrne, 1995].

\subsubsection{RSCM and Thermochronological Results}

[32] Samples were collected within the two anticlines for both RSCM T (Chayiang Formation) and ZHe dating (Tachien formation). Results are projected together with previous thermochronological constraints on Figure 9. 


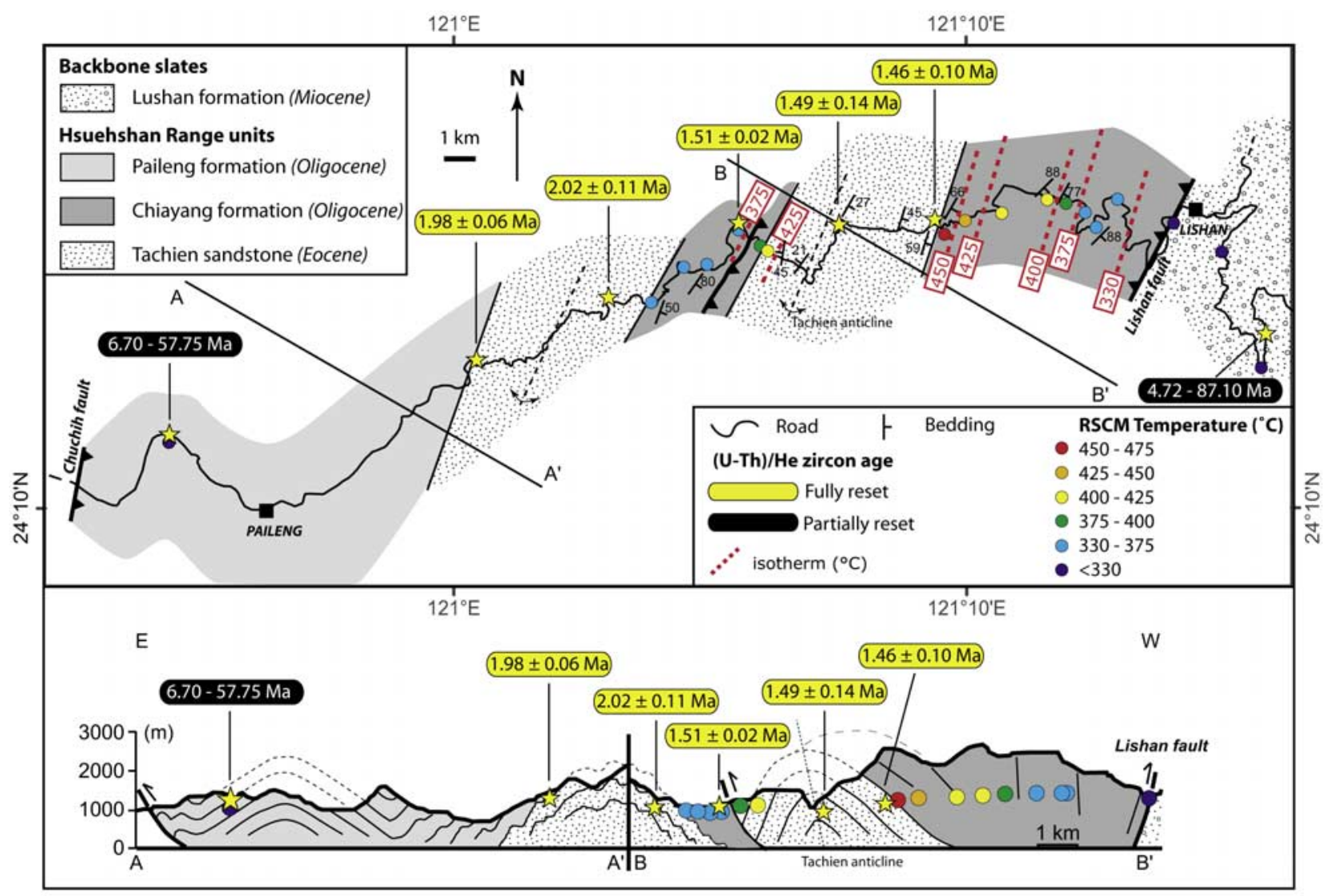

Figure 8. (top) Geological map of the HR units and western BS along the central cross-island highway, modified from Tillman and Byrne [1995] (see Figures 1 and 4 for location). Structural data are from this study and Clark et al. [1993]. RSCM temperatures obtained in this region (blue to red circles) were used to determine the position of the isotherms for peak metamorphic temperatures. Zircon (U-Th)/He ages from this study are represented. Minimum and maximum zircon (U-Th)/He ages are given for each partially reset sample (see Table 3). (bottom) Structural profile modified from Tillman and Byrne [1995] with projected RSCM and thermochronologic data (location of transect on top plot).

Within the two anticlines, the Chayiang Formation exhibits a contrasted thermal history as attested by the different RSCM T patterns. Within the eastern flank of the Tachien anticline, peak $\mathrm{T}$ increase westward from $\sim 350^{\circ} \mathrm{C}$, close to the Lishan fault, up to $\sim 475^{\circ} \mathrm{C}$ at the top of the Tachien sandstone. Therefore $\mathrm{T}$ increases downsection within the Chayiang Formation with a normal geothermal gradient of about $25^{\circ}-30^{\circ} \mathrm{C} / \mathrm{km}$, as determined from our structural measurements. As also reported by Clark et al. [1993], we have observed biotite locally within the Tachien sandstone. Biotite appears in this case as coarse flakes generally with an altered morphology at the grain boundaries. There are almost no other metamorphic minerals in these rocks such as phengites, well-crystallized chlorites or epidotes, which would be expected with biotite at the obtained RSCM $\mathrm{T}$. In addition, we did not observe biotite in the Chayiang slates where RSCM T have been obtained. Altogether, we believe that this biotite may have a detrital origin, and might not be an indicator of late Cenozoic metamorphism. Two samples were collected on both sides of the thrust separating the two anticlines: sample $\mathrm{C} 04-14\left(\mathrm{~T} \sim 417^{\circ} \mathrm{C}\right)$ was collected in the hanging wall whereas sample $\mathrm{C} 04-15\left(\mathrm{~T} \sim 385^{\circ} \mathrm{C}\right)$ was taken from the footwall. The difference in $\mathrm{T}\left(\sim 30^{\circ} \mathrm{C}\right)$ is significantly higher than the standard error on RSCM T: this suggests that displacement on the fault may have occurred after peak $\mathrm{T}$ have been attained on both sides. All other RSCM T obtained in the western anticline are almost constant $\left(330^{\circ}-355^{\circ} \mathrm{C}\right)$. In the westernmost Paileng Formation, RSCM T are below $330^{\circ} \mathrm{C}$ (Figure 8).

[33] Six sandstone samples were analyzed for $\mathrm{ZHe}$ dating. Within the eastern Tachien anticline, samples C0241 and $\mathrm{C} 04-03$ from the Tachien sandstone were dated to $1.46 \pm 0.10 \mathrm{Ma}$ and $1.49 \pm 0.14 \mathrm{Ma}$ respectively. A sandstone interbedded within the Chaiyang Formation was collected in the immediate footwall of the thrust between the two anticlines (C04-18) and yielded an age of $1.51 \pm$ $0.02 \mathrm{Ma}$. Two sandstone samples from the core of the western anticline had ages of $2.02 \pm 0.11 \mathrm{Ma}$ (C04-24) and $1.98 \pm 0.06 \mathrm{Ma}(\mathrm{C} 04-29)$. Last, a sandstone sample from the western Oligocene Paileng Formation was ana- 

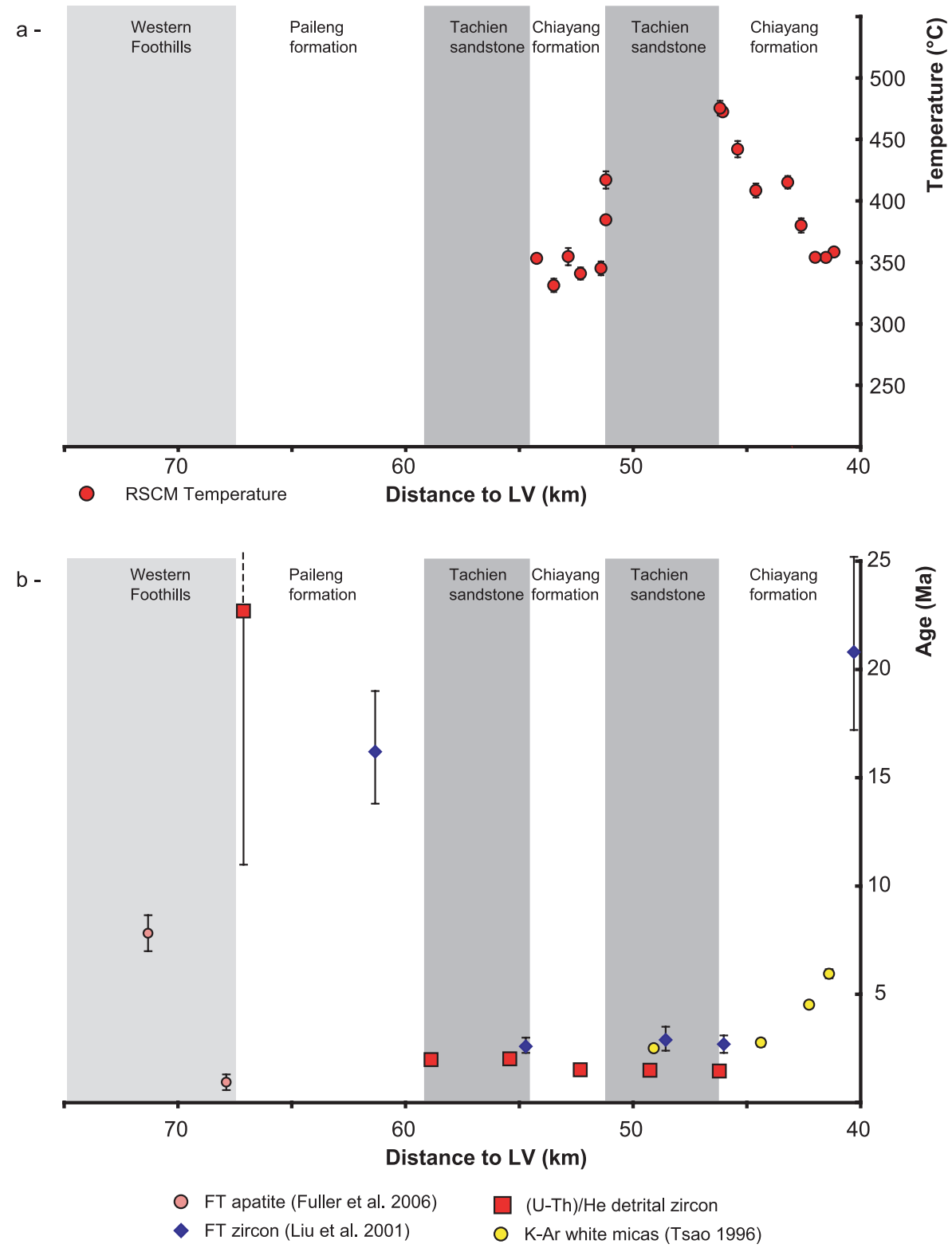

Figure 9. Expansion of Figure 5 in the Hsuehshan Range units. (a) RSCM temperature and (b) thermochronologic data in the western BS and in the HR units along the central cross-island highway. Thermochronologic data: (U-Th)/He on detrital zircon (this study, Table 3), zircon fission tracks $(\chi 2$ ages from Liu et al. [2001] (Table S1)), apatite fission tracks [Fuller et al., 2006] and K-Ar on white micas clay fraction [Tsao, 1996] (Table S2). Predictions of the model of Barr et al. [1991] that assumes 25\% of constant underplating below the wedge do not appear here because they fall outside the values represented on the graph (see Figure 5: RSCM T $<330^{\circ} \mathrm{C}$, and non reset cooling ages). The absolute uncertainty on RSCM temperature is $\pm 50^{\circ} \mathrm{C}$.

lyzed but it appeared to be not fully reset. Other previously published thermochronologic constraints are represented on Figure 9b. It is worth mentioning that the positions of ZFT data by Liu et al. [2001] as well as K-Ar ages from Tsao [1996] retrieved by georeferencing the source maps are not precise. Central ages calculated from ZFT data generally show high uncertainties in the HR. The $\chi^{2}$ ages appear to be significantly different from central ages (Table S1 and
Figure 9b) because of probable large variance in annealing characteristics. The $\chi^{2}$ ages seem more representative in the HR and we therefore subsequently use these. The ZFT ages all fall in the range 2.6-2.9 Ma and do not exhibit any particular trend. K-Ar ages on white micas are similar to the ZFT ages and are even younger at some locations. This is not expected if the closure $\mathrm{T}$ usually assumed for these 


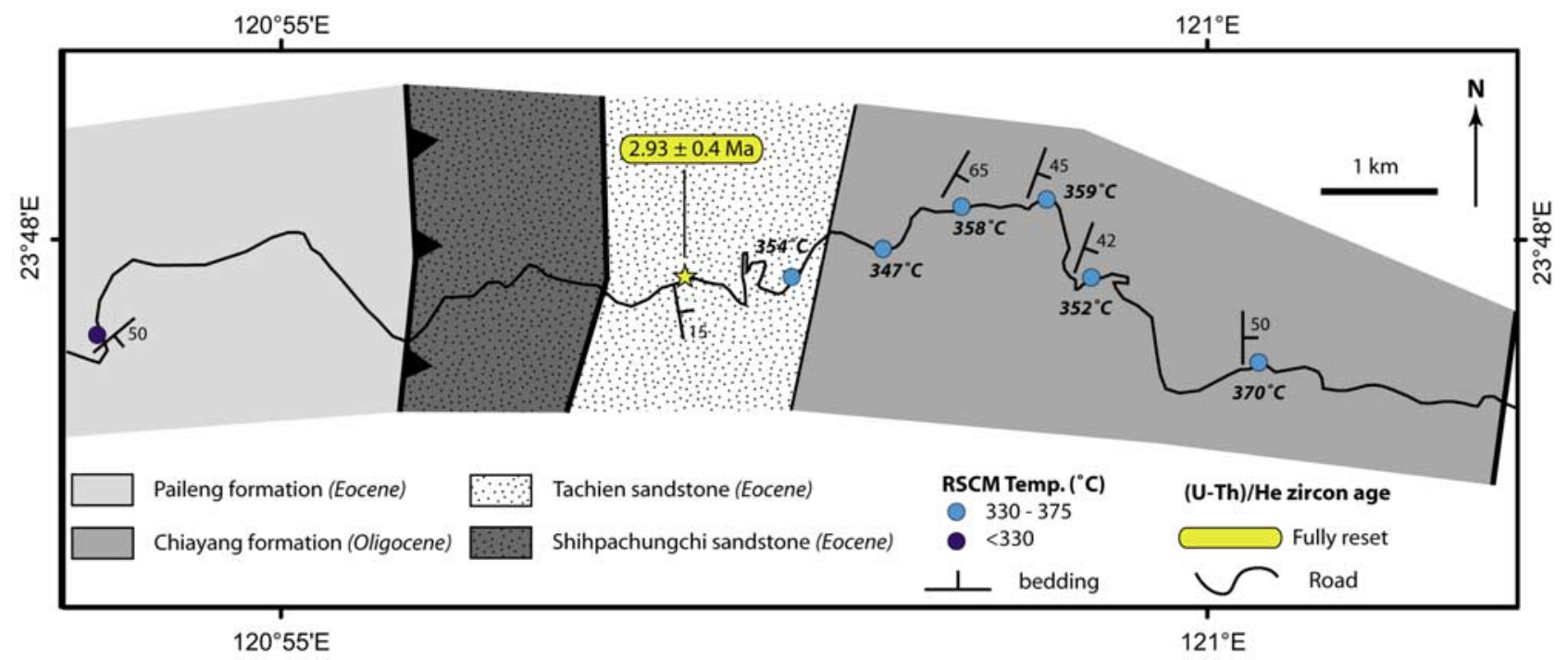

Figure 10. Geological map of the HR along the mid-Taiwan highway (Choushui river; see Figure 1 for location), modified from $H o$ [1988]. Structural data are from this study. RSCM temperatures are depicted by the blue to red circles. The unique zircon (U-Th)/He age (Tachien sandstone) obtained in this area is shown.

thermochronometers are considered. We may therefore question the significance of some of these data.

\section{Thermometric and Chronological Constraints Along the Choushui and Southern Highway Transects}

\subsection{Choushui Highway (Central Transect)}

[34] This short transect is located along the Choushui river (Figure 1) and offers good exposure for the southern exhumed HR units (Figure 10). The structure of the HR units is simpler than along the northern transect. Only one single asymmetric anticline, similar to eastern Tachien anticline to the north, is observed. The core of this anticline is constituted of the Eocene Shihpachungchi Formation [Ho, 1988], which is however not easily distinguishable from the adjacent Tachien sandstone.

[35] Six samples were collected in the Chayiang Formation for RSCM thermometry and all yielded similar $\mathrm{T}$ in the range $345^{\circ}-370^{\circ} \mathrm{C}$ (Figure 10). This almost flat gradient in RSCM T is very similar to the pattern observed over the western anticline along the northern profile. One sample was collected farther west in the Paileng Formation and yielded a RSCM T below $330^{\circ} \mathrm{C}$ (H04-10). Only one sandstone sample (H04-08) was collected for $\mathrm{ZHe}$ within the Tachien Formation and yielded an age of $2.93 \pm$ $0.43 \mathrm{Ma}$. This age is older than all the ages obtained in the Tachien Formation along the northern profile from both the western and eastern anticlines. ZFT data are available for this transect [Liu et al. 2001] (Table S1). The central ages fall in the range 3.9-4.7 Ma and do not show significant differences with the $\chi^{2}$ ages $(2.4-4.3 \mathrm{Ma})$. These ages are older than those obtained in the HR along the northern profile, indicating that exhumation rates of the HR units have been lower along this transect than farther north or else indicating that these units have not yet attained an exhumation steady state in the sense of Willett and Brandon [2002].

\subsection{Southern Highway (Southern Transect)}

\subsubsection{Structural Background}

[36] The southern cross-island highway offers the opportunity to cross the BS and TC in southern Taiwan, but not the HR units as they are absent in this area (Figure 1). From west to east, this profile crosses a thin Lushan Formation, a thick Pilushan Formation, the Tailuko belt, the Yuli belt and finally again the Pilushan Formation before reaching the LV (Figures 11 and 12). The Pilushan Formation thus surrounds on both sides the pre-Tertiary TC. Along this section, the stratigraphy [e.g., Stanley et al., 1981; Warneke and Ernst, 1984], detailed structural trends [Crespi et al., 1996; Fisher et al., 2002; Tillman and Byrne, 1995, 1996; Warneke and Ernst, 1984] as well as metamorphism [Warneke and Ernst, 1984] have been studied.

[37] In the Lushan and western Pilushan, the bedding S0 is E-dipping, and the dip angle increases eastward. In both units all kinematic criteria from S-C planes, asymmetric pressure shadows around quartz porphyroblasts and up to multimeters-scale asymmetric structures indicate a consistent top-to-the NW sense of shear. At a larger scale, S0 and S1 form a fan through the Pilushan Formation and both dip steeply to the west at the contact with the Tailuko belt. This fan is comparable to the cleavage fan observed along the northern transect [Pulver et al., 2002] and is located at a similar distance from the LV. In the case of the pre-Tertiary TC in both the Tailuko and Yuli belts, bedding can typically 


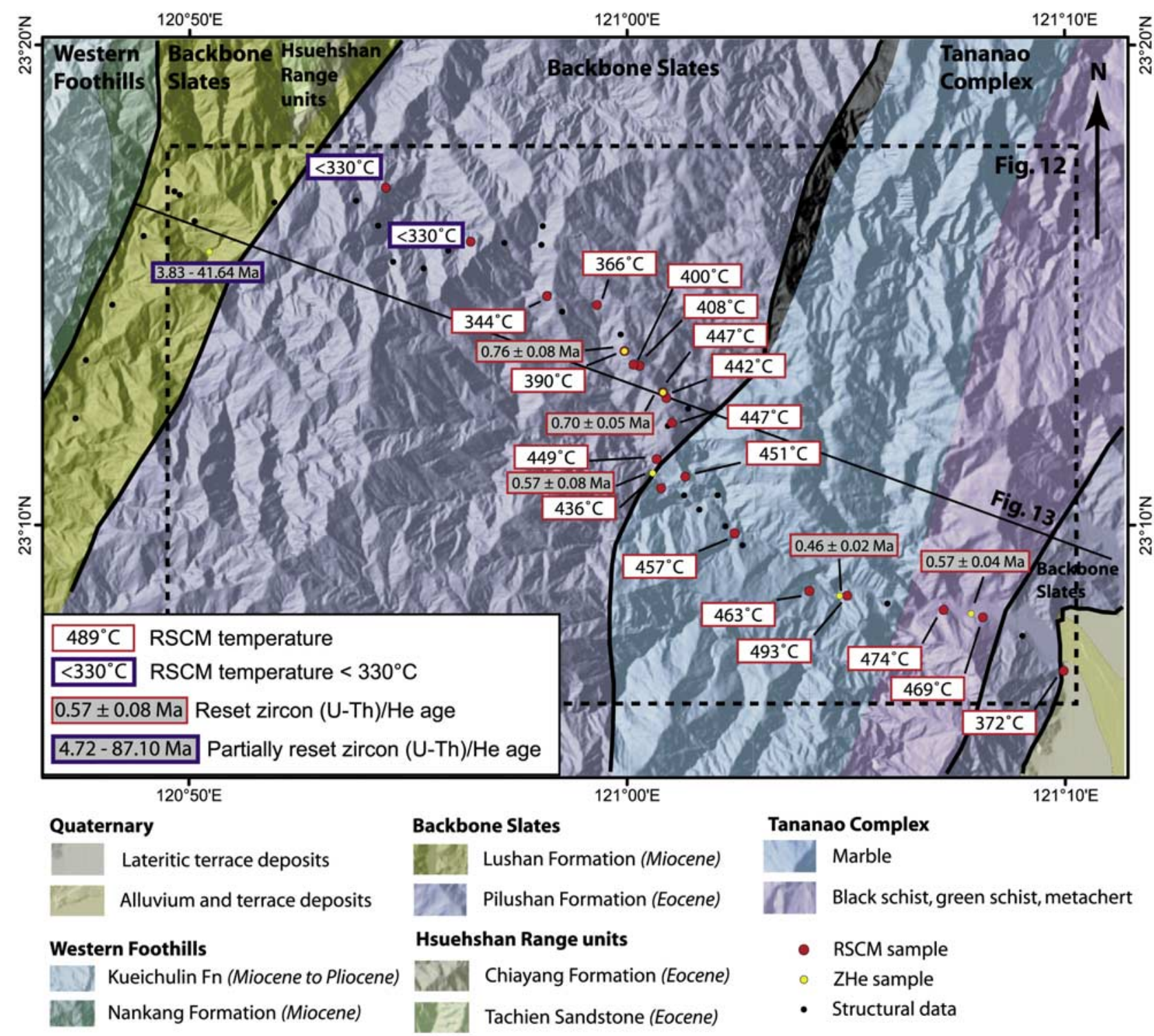

Figure 11. Geological map of southern Taiwan in the vicinity of the southern cross-island highway (see Figure 1 for location). The main two structural units are from W to E: BS and TC. Mean RSCM temperatures (Table 2) and zircon (U-Th)/He ages (Table 3) from this study are represented. Minimum and maximum zircon (U-Th)/He ages are given for each partially reset sample (see Table 3). Box indicates location of Figure 12.

be observed where there are strong lithological contrasts between schists and sandstones for instance. Both bedding (S0) and main foliation (S1) are relatively steep and generally W-dipping in the units. The contact between the Tailuko and Yuli Belts of the TC appears as an imbricate thrust zone which truncates different lithologic units within each Formation, confirming the tectonic nature of the zone [Warneke and Ernst, 1984]. S0 and S1 are still dipping to the west in the Yuli Belt, which overthrusts the Pilushan Formation farther east [Warneke and Ernst, 1984]. The pattern of deformation is relatively complex in the Pilushan Formation outcropping along the LV. Fisher et al. [2002] actually show that there is no systematic trend in cleavage directions in this unit except in the southernmost region close to Taitung where cleavage is mostly W-dipping (Figure 12). Stretching lineation is well documented in the area and is relatively parallel to the main strike indicating a top to the NE noncoaxial deformation [Fisher et al., 2002]. 5.2.2. RSCM and Thermochronological Results

[38] Along this southern transect, 23 samples were collected for RSCM thermometry (Figures 11, 12, and 13). In the Lushan and westernmost Pilushan Formations all samples yielded T below $330^{\circ} \mathrm{C}$. Moving eastward within the Pilushan Formation, RSCM T increase gradually from 


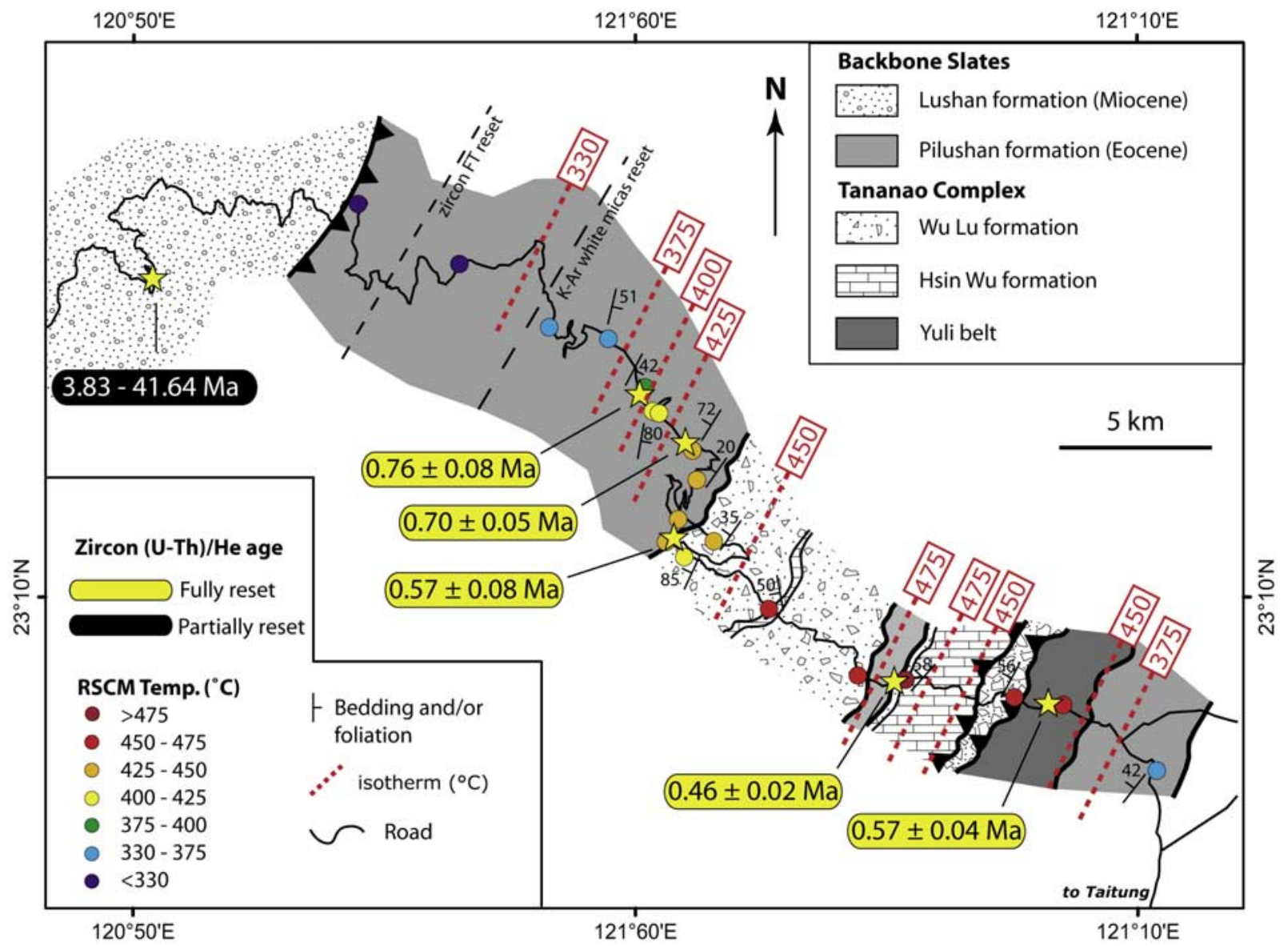

Figure 12. Geological map of the BS and TC along the southern cross-island highway, modified from Warneke and Ernst [1984] (see Figures 1 and 11 for location). Structural data are from this study and from Ernst and Warneke [1983]. RSCM temperatures obtained in this region (blue to red circles) were used to determine the position of the isotherms for peak metamorphic temperatures. Zircon (U-Th)/He ages from this study are represented. Minimum and maximum zircon (U-Th)/He ages are given for each partially reset sample (see Table 3). The approximate positions of the limit for resetting of ZHe, ZFT, and $\mathrm{K}-\mathrm{Ar}$ on white micas are represented here by the different black dashed lines.

below $330^{\circ} \mathrm{C}$ up to $\sim 450^{\circ} \mathrm{C}(\mathrm{S} 02-24)$ at the contact with the basement (Tailuko belt). From our structural measurements, we estimate an apparent thermal gradient of $15^{\circ}-20^{\circ} \mathrm{C} / \mathrm{km}$, which is inverted because $\mathrm{T}$ increases upsection. As in the case of the northern transect, this inverted thermal gradient roughly coincides with the location of the observed cleavage fan. In the TC units, RSCM-T are systematically higher than $450^{\circ} \mathrm{C}$ and show little variations from $450^{\circ} \mathrm{C}$ up to $493^{\circ} \mathrm{C}$ (sample S02-14). Farther east, within the Pilushan formation present along the LV, RSCM-T abruptly decrease and two samples provided $\mathrm{T}$ of $354^{\circ} \mathrm{C}(\mathrm{SO} 2-06)$ and $372^{\circ} \mathrm{C}$ (SO2-09).

[39] Six samples were collected for $\mathrm{ZHe}$ within the different formations (Figures 11 and 12). In the Lushan Formation, sample S04-08 was not fully reset. Within the Pilushan Formation, three samples tend to indicate a slight gradient with an eastward decrease in ZHe ages from $0.76 \pm$ $0.08 \mathrm{Ma}$ (S04-06) down to $0.57 \pm 0.08 \mathrm{Ma}$ (S04-04). The $\mathrm{TC}$ yielded very young $\mathrm{ZHe}$ ages of $0.46 \pm 0.02 \mathrm{Ma}(\mathrm{S} 04-02)$ and $0.57 \pm 0.04 \mathrm{Ma}$ (S04-01), in both the Tailuko and Yuli Belts respectively. These data are shown on Figures 13 and 14 with all other thermochronological constraints provided by ZFT [Tsao, 1996; Liu et al., 2001], AFT [Willett et al., 2003; Fuller et al., 2006] and K-Ar ages on white micas [Tsao, 1996]. All thermochronometers are only partially reset in the Lushan Formation (Figure 13). They then progressively become fully reset in Pilushan going eastward toward the TC (Figures 13 and 14). In the area where ZFT ages are reset, data from Tsao [1996] show consistent pooled and $\chi^{2}$ ages, whereas central ages are systematically and significantly higher than $\chi^{2}$ ages in Liu et al.'s [2001] data set. In this latter case, we rather considered the $\chi^{2}$ ages, as we did for the ZFT ages of the HR units from the northern transect. These $\chi^{2}$ ages from Liu et al. [2001] show a better agreement with the central ages obtained by Tsao [1996]. The ZFT data do not show a particular trend except perhaps slightly younger ages in the TC than in the western 

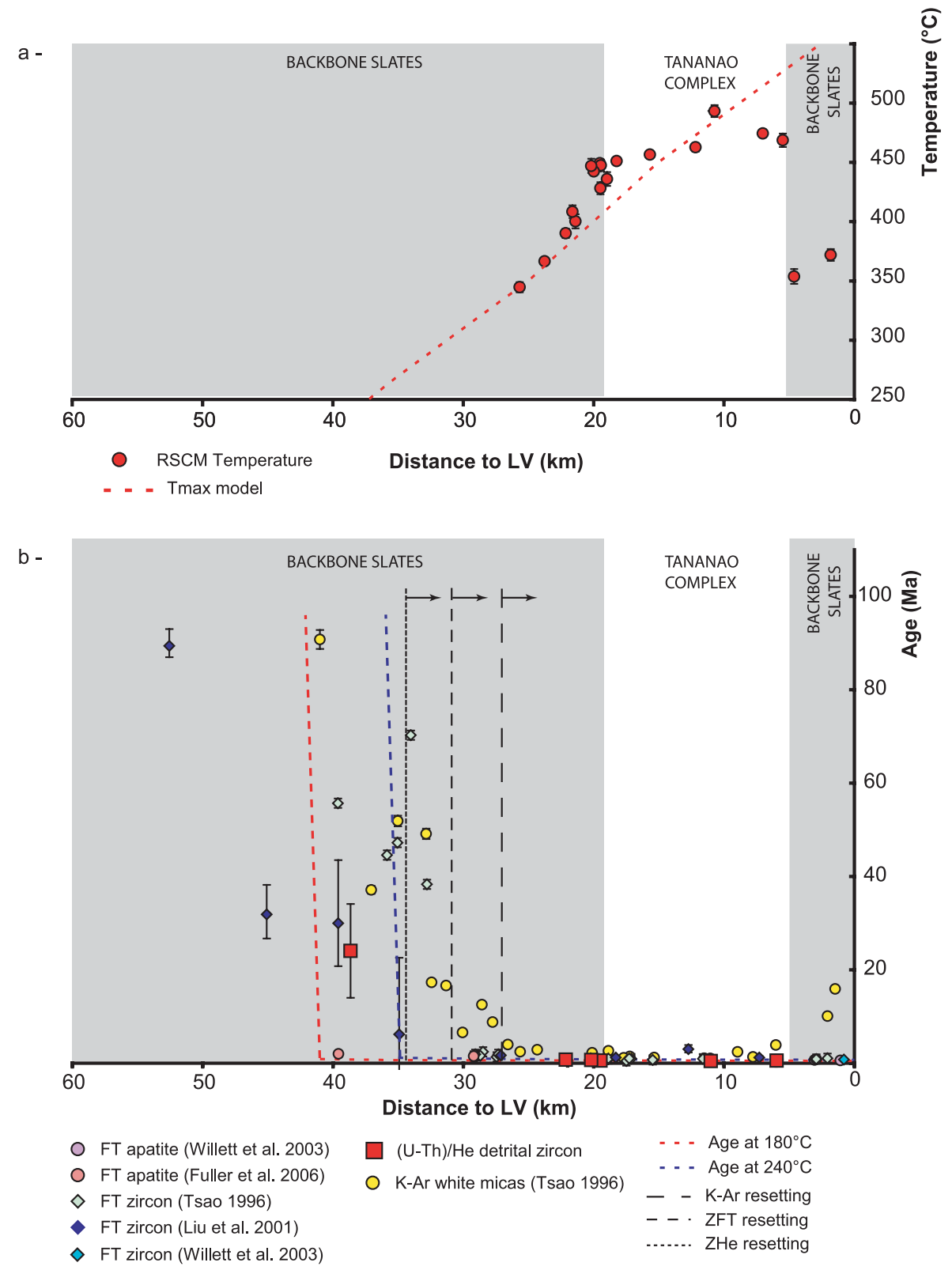

Figure 13. RSCM temperatures and thermochronologic data projected on a N110 profile from the WF (W) to the LV (E). The horizontal axis indicates the horizontal distance to the LV along this transect. (see Figure 11 for location). (a) RSCM temperatures obtained in this study (Table 2) (mean value with 1- $\sigma$ standard error). Red dashed line reports the predictions of the model of Barr et al. [1991] that assumes $25 \%$ of constant underplating below the wedge. The absolute uncertainty on RSCM temperature is $\pm 50^{\circ} \mathrm{C}$. (b) Thermochronologic data: (U-Th)/He on detrital zircon (this study, Table 3), zircon fission tracks [Tsao, 1996] ( $\chi 2$ ages from Liu et al. [2001] (Table S1)), apatite fission track [Willett et al., 2003; Fuller et al., 2006] and K-Ar on white mica clay fractions [Tsao, 1996] (Table S2). In the western BS black dashed lines indicate the limit of resetting for $(\mathrm{U}-\mathrm{Th}) / \mathrm{He}$ on zircon, fission tracks on zircon and $\mathrm{K}-\mathrm{Ar}$ on white micas. Red and blue dashed lines report the predictions in terms of $\mathrm{ZHe}\left(180^{\circ} \mathrm{C}\right.$ closure temperature $)$ and $\mathrm{ZFT}\left(240^{\circ} \mathrm{C}\right.$ closure temperature) ages respectively of the model of Barr et al. [1991] that assumes $25 \%$ of constant underplating below the wedge. 


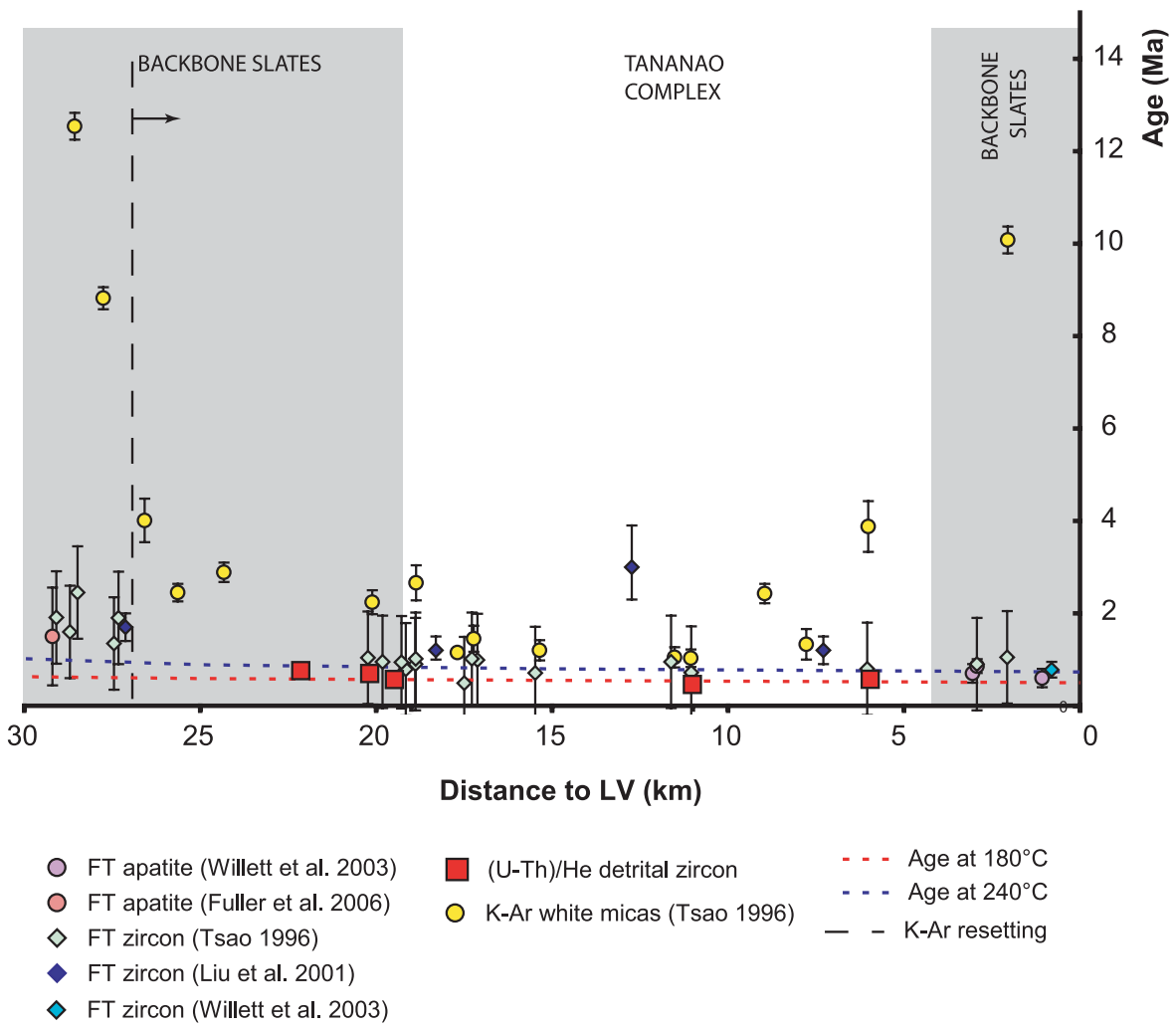

Figure 14. Thermochronologic data in the eastern BS and in the TC along the southern cross-island highway (zoom from Figure 13b). Thermochronologic data: (U-Th)/He on detrital zircon (this study, Table 3), zircon fission tracks [Tsao, 1996] ( $\chi 2$ ages from Liu et al. [2001] and Willett et al. [2003] (Table S1)), apatite fission track [Willett et al., 2003; Fuller et al., 2006] and K-Ar on white micas clay fraction [Tsao, 1996] (Table S2). In the BS, the black dashed line indicates the limit of resetting for K-Ar ages on white micas. Red and blue dashed lines report the predictions in terms of $\mathrm{ZHe}\left(180^{\circ} \mathrm{C}\right.$ closure temperature) and $\mathrm{ZFT}\left(240^{\circ} \mathrm{C}\right.$ closure temperature) respectively of the model of Barr et al. [1991] that assumes $25 \%$ of constant underplating below the wedge.

Pilushan. Interestingly, ZFT ages in the Pilushan Formation along the LV are all in the range $0.8-1.1 \mathrm{Ma}$, and are thus similar to the ages obtained in the Pilushan Formation on the western flank of TC. Last, K-Ar on white micas show minimum ages within the Tailuko Belt in the range $1-1.5 \mathrm{Ma}$ whereas ages increase on both sides. In the Yuli Belt, three $\mathrm{K}$-Ar ages fall in the range 1.3-3.9 $\mathrm{Ma}$ and in the Pilushan Formation $\mathrm{K}-\mathrm{Ar}$ ages increase westward from $\sim 2.25 \mathrm{Ma}$ up to $\sim 4 \mathrm{Ma}$.

\section{Discussion}

\subsection{Significance of RSCM Data Relative to the Late} Cenozoic Orogeny in Taiwan

6.1.1. Consistency Between RSCM Temperatures, Petrology, and Thermochonology and Evidence That Peak Metamorphic Temperatures Are Late Cenozoic

[40] Metamorphic T estimates by conventional petrology are very scarce throughout the Taiwan mountain belt [e.g., Ernst and Jahn, 1987; Faure et al., 1991]. The mineral parageneses used for the previously proposed petrologic estimates generally compose the main foliation, and the P-T conditions proposed from there along the southern and central highways were considered to be representative of the late Cenozoic collision [e.g., Ernst, 1983; Ernst and Jahn, 1987; Faure et al., 1991]. If we consider these previous estimates, our RSCM T are systematically equal or even higher than those obtained by petrological methods at about the same location. This is also the case when RSCM T are compared to T obtained by Yui [2005] from the calcite-graphite isotopic thermometer. However, both these petrologic data and isotopic estimates may be questionable. In fact, $\mathrm{P}-\mathrm{T}$ conditions were previously determined from standard and outdated petrogenetic grids, and are actually mainly based on an empiric comparison of mineral parageneses and chemistry in Taiwan with other metamorphic belts, mostly the Franciscan complex in California, USA. A reassessment of these P-T conditions with modern thermodynamic databases is therefore needed for an accurate comparison with RSCM T. Moreover, the applicability of the calcite-graphite isotopic thermometer is severely doubtful below $500^{\circ} \mathrm{C}$ [e.g., Dunn, 2005]. 


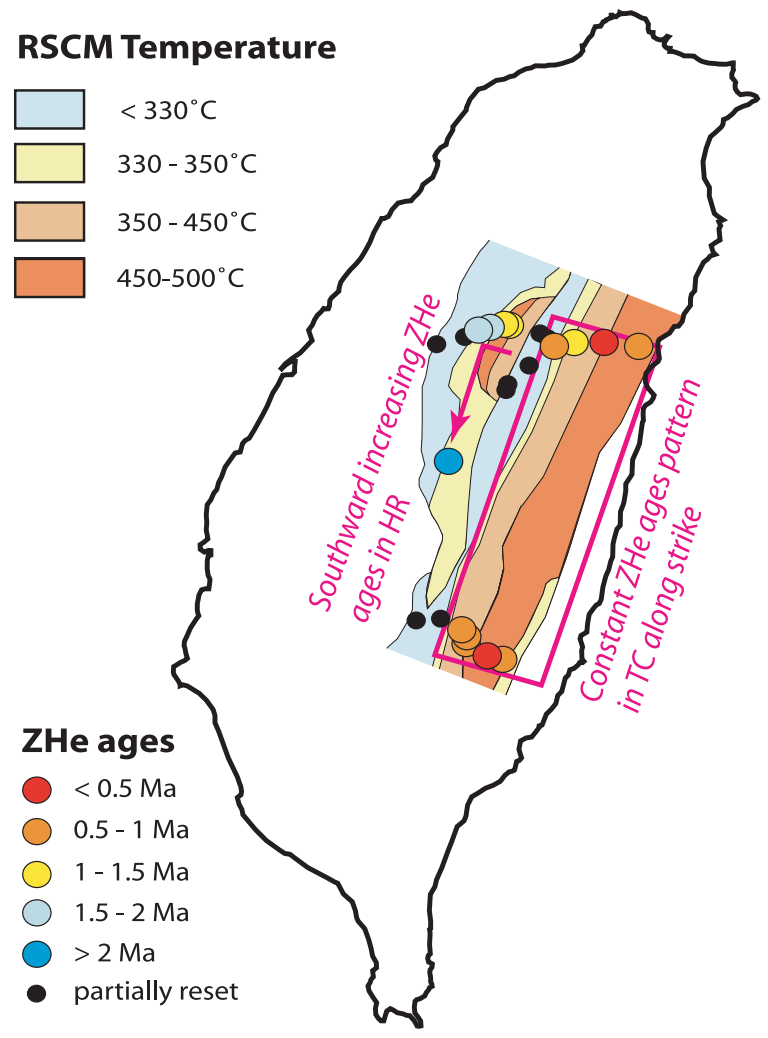

Figure 15. Schematic map showing thermal metamorphism (RSCM temperatures) and (U-Th)/He ages on zircon over central Taiwan. Contours were drawn by laterally extrapolating the results obtained on the three transects investigated in this study (Figure 1). Note the laterally constant pattern over the Tananao basement in opposition to the N-S progressive exhumation of the HR units.

[41] On the other hand, the RSCM data suggest that metamorphic $\mathrm{T}$ were locally high $\left(>450^{\circ} \mathrm{C}\right)$ although almost no index metamorphic mineralogy or only poorly crystallized phyllosilicates are observed. This is not a particularity of the Taiwan mountain belt as this was also observed for similar RSCM T conditions and lithologies by Beyssac et al. [2004] in the upper lesser Himalaya of Nepal below the MCT zone, or else by Negro et al. [2006] above the Beni Bousera peridotite in the Filali terranes (northern Morocco). An explanation to this absence of mineralogy is a non favorable lithology (slates, sandstones, limestones), and therefore a nonfavorable initial chemistry. However, similar lithologies metamorphosed under the same $\mathrm{T}$, but much higher $\mathrm{P}$, in the western Alps for instance show a rich mineralogy with lawsonite, carpholite, well-crystallized phengites, chloritoid and garnet [Agard et al., 2001; Bousquet et al., 1998]. In the case of the probable P-T conditions encountered in Taiwan [e.g., Ernst and Jahn, 1987], reference petrogenetic grids [e.g., Spear, 1993; Holland and Powell, 1998] predict the presence of musco- vite, chlorite, albite, epidote, chloritoid and biotite for these lithologies. All these minerals, except chloritoid, have in fact been observed in Taiwan [e.g., Ernst and Jahn, 1987]. On the other hand, the limiting kinetics of reactions, with regards to the probable high burial and exhumation rates, may explain the poor expression of the mineralogy and the poor cristallinity of the minerals.

[42] The timing of the peak metamorphic $\mathrm{T}$ retrieved by RSCM is a key question for the interpretation of these data. RSCM T obtained for the rocks of the slate belt (HR+ BS) are expected to have been acquired during the late Tertiary orogeny or within the initial passive margin basins, because these rocks have not been involved in any other orogenic and thermal event. The timing of RSCM T is however particularly critical in the case of the TC because of its poly metamorphic history. Wang et al. [1998] dated the main mylonitization phase in the Hoping gneisses (Figure 1) to $\sim 3-4 \mathrm{Ma}$ on the basis of ${ }^{40} \mathrm{Ar}-{ }^{39} \mathrm{Ar}$ ages on fine grained biotites, indicating that these rocks had cooled from $\mathrm{T}$ as high as $350^{\circ} \mathrm{C}$ during the recent orogeny. In the case of the Chipan gneiss along the central cross-island highway, Lo and Onstott [1995] report a fully reset ${ }^{40} \mathrm{Ar}-{ }^{39} \mathrm{Ar}$ age on biotite of $7.7 \mathrm{Ma} .{ }^{40} \mathrm{Ar}-{ }^{39} \mathrm{Ar}$ ages on coarse hornblendes and muscovites of the Chipan gneiss are only partially reset with the presence of second generation fine grained actinolitic amphiboles and phengites [Lo and Onstott, 1995]. These authors propose that the ${ }^{40} \mathrm{Ar}^{39} \mathrm{Ar}$ ages of these secondgeneration minerals are of 7.8 and $6.4 \mathrm{Ma}$ on amphiboles and phengites respectively, based on the Ar isotopic composition of the actinolitic reaction rim of amphiboles and on the abundance of phengites flakes with respect to coarse muscovites. This indicates that these rocks of the eastern TC were potentially at $\mathrm{T}$ as high as $450^{\circ}-500^{\circ} \mathrm{C}$ during the recent orogeny in Taiwan, a value consistent with that obtained from RSCM. Lo and Onstott [1995] also quantitatively showed that rapid burial and exhumation of these rocks, with a short thermal overprinting of probably less than 3 to $4 \mathrm{Ma}$, could be sufficient to explain why primary coarse muscovites and hornblendes were not fully reset for ${ }^{40} \mathrm{Ar}-{ }^{39} \mathrm{Ar}$. They use for that the thermal model of [Barr et al., 1991], which predicts peak metamorphic $\mathrm{T}$ and exhumation rates consistent with RSCM data and thermochronological constraints in this part of the wedge (Figure 5). The geochronological data of Lo and Onstott [1995] therefore indicate that the T documented by RSCM may possibly be representative of the last orogeny in the case of the polymetamorphic basement rocks of the TC. This idea is also essentially comforted by the continuity in RSCM T across the boundary between the Eocene Pilushan formation and the TC, on both the northern and southern transects (Figures 6, 7, 12 and 13). The spatial distribution of RSCM $\mathrm{T}$ is also strongly correlated with the geometry of the tectono-stratigraphic ensembles that were acquired during the last collision. In addition, the eastward progressive increase of $\mathrm{T}$ across the BS and the TC appears spatially consistent with the increasing pervasive ductile deformation usually associated to the most recent orogeny [Ernst and Jahn, 1987; Faure et al., 1991; Crespi et al., 1996; Pulver et al., 2002]. We acknowledge for the possibility that RSCM T 
obtained in the case of the polymetamorphic basement rocks of the TC may have been acquired in a previous thermal event, possibly Cretaceous in age. However, we believe that altogether these observations and the geochronological constraints of Lo and Onstott [1995] indicate that RSCM $\mathrm{T}$ of the $\mathrm{TC}$ rocks are possibly representative of the last thermal event in Taiwan.

[43] In Figure 15, we tentatively map at the scale of the mountain belt RSCM T superposed with obtained ZHe ages over Taiwan: both data sets show a remarkable spatial correlation. In general, RSCM T show a significant consistency with all thermochronological data, since $\mathrm{T}$ higher than the $330^{\circ} \mathrm{C}$ resolution limit are systematically associated with full Cenozoic resetting of ZHe and ZFT ages, as well as of $\mathrm{K}$-Ar ages on white micas (Figures 5 and 13). The inverse (RSCM T $<330^{\circ} \mathrm{C}$ and non fully reset thermochronometers) is also true.

\subsubsection{A Kinetic Effect During the Young and Rapidly Deforming Taiwan Orogeny?}

[44] On the basis of the arguments discussed above, we hereafter assume that RSCM T obtained across the Taiwan mountain belt have been acquired during the most recent thermal event. This orogen has resulted from a very young orogenic phase with rapid and unusually high deformation, burial and exhumation rates. A technical challenge of this study was thus to test the applicability of the RSCM method to this particular case. Indeed, RSCM has been initially calibrated with samples from late Mesozoic to Cenozoic alpine-type mountain belts (Alps, Greece, Japan [Beyssac et al., 2002a]) that have evolved at slower geological rates. For instance, the duration of a subduction/exhumation cycle is estimated to $\sim 15 \mathrm{Ma}$ in the western Alps of Italy [Federico et al., 2005], which is significantly longer than in Taiwan where the collision started $\sim 4$ to $\sim 8 \mathrm{Ma}$ ago $[C h i$ et al., 1981; Lin et al., 2003; Sibuet and Hsu, 2004]. Also, the RSCM method has also been successfully applied to decipher the metamorphic evolution of the Lesser Himalaya of Nepal [Beyssac et al., 2004] where the long-term cooling rates (from $15^{\circ}$ to $100^{\circ} \mathrm{C} / \mathrm{Ma}$ [Bollinger et al., 2006]) appear lower than in Taiwan (see below). Because experimental studies of graphitization have shown that it is a kinetically controlled process at laboratory timescales [e.g., Beyssac et al., 2003b], it could be possible that the degree of graphitization is dependent on the heating and cooling rates. If so, peak metamorphic $\mathrm{T}$ could have been underestimated in Taiwan using RSCM, which is not observed when comparing RSCM T with other T estimates as discussed above. Moreover, Sweeney and Burnham [1990] have shown that during diagenesis and low-temperature metamorphism, the mean degree of organization for disordered CM is mostly controlled by $\mathrm{T}$, and that it is essentially insensitive to the heating rate and duration of the thermal event. Although their study is based on a simple kinetic model of carbonification and early graphitization that is applicable to $\mathrm{T}$ below $300^{\circ} \mathrm{C}$, it seems reasonable to consider that kinetic limitations to graphitization, if any, should be negligible at higher T. Although deformation and exhumation rates in Taiwan are unusually rapid, we consider that the degree of graphitization measured by RSCM does relate primarily to the maximum $\mathrm{T}$ encountered by the rocks.

6.1.3. Metamorphism: Static in Hsuehshan, Dynamic in Tananao?

[45] In the $\mathrm{TC}$, peak metamorphic $\mathrm{T}$ from $\sim 350^{\circ} \mathrm{C}$ up to $\sim 500^{\circ} \mathrm{C}$ are associated with an intense pervasive ductile deformation and a poorly expressed but existing mineralogy (Table 1). On the contrary, similar high $\mathrm{T}$ in the core of the HR units (Tachien anticline) are associated with brittle to weakly ductile deformation, but without any particular expressed mineralogy (Figures 6 and 8). Biotite has been described in the core of the HR units [Clark et al., 1993], but its texture suggests it is detrital and not representative of the metamorphic grade of these rocks. Also other minerals, expected to be associated to biotite at $\mathrm{T}$ as high as $475^{\circ} \mathrm{C}$ (phengite, chlorite and epidote) are scarcely observed in the HR units. In other words, if deformation and mineralogy of the TC rocks are representative of their metamorphic grade, the HR units rather look like poorly metamorphosed sedimentary rocks in contrast with their estimated peak metamorphic $\mathrm{T}$ of up to $475^{\circ} \mathrm{C}$. To explain the differences between the $\mathrm{HR}$ and $\mathrm{TC}$ units, we propose that metamorphism of the HR units has been acquired in the initial passive margin basins. Indeed, the HR units are composed of syn- to post-rift sediments of the Chinese passive margin that were incorporated into the Taiwan mountain belt during the collision. Because the Eurasian margin is characterized by geothermal gradients of $\sim 30^{\circ} \mathrm{C} / \mathrm{km}$ [e.g., Zhou et al., 2003], similar to the thermal gradient retrieved from RSCM for the HR units, the peak metamorphic T observed in these units might be inherited from the initial thermal structure of the margin associated with the opening of the South China Sea during the Oligo-Miocene. Such inherited 'static' metamorphism is actually compatible with the absence of intense pervasive deformation observed in the HR units. On the contrary, we propose that metamorphism in the TC is rather 'dynamic' with a probable initial thermal component inherited from the margin, but overprinted by higher $\mathrm{T}$ during late Cenozoic subduction/collision processes. Although peak $\mathrm{T}$ in the HR units have probably been acquired within the passive margin before incorporation into the deforming Taiwan wedge, they do provide key information on the amount of exhumation. From RSCM T and the observed thermal gradient, we estimate a minimum of $\sim 15 \mathrm{~km}$ of exhumation over the last few Ma for the HR along the northern transect.

\subsection{Significance of Thermochronologic Data \\ 6.2.1. Comparison With Previous Data Sets}

[46] As summarized through this manuscript, there is a large thermochronologic database covering most of the Taiwan mountain belt. Thermochronologic data for supposedly higher closure $\mathrm{T}\left({ }^{40} \mathrm{Ar}-{ }^{39} \mathrm{Ar}\right.$ ages on biotite and muscovite) are available only in eastern Taiwan, but their interpretation is not straightforward because of partial resetting and recrystallization [Lo and Onstott, 1995]. The data set of K-Ar ages on thin fraction of white micas by Tsao [1996] covers most of the Taiwan mountain belt but should be taken cautiously. Indeed, Tsao [1996] considered 


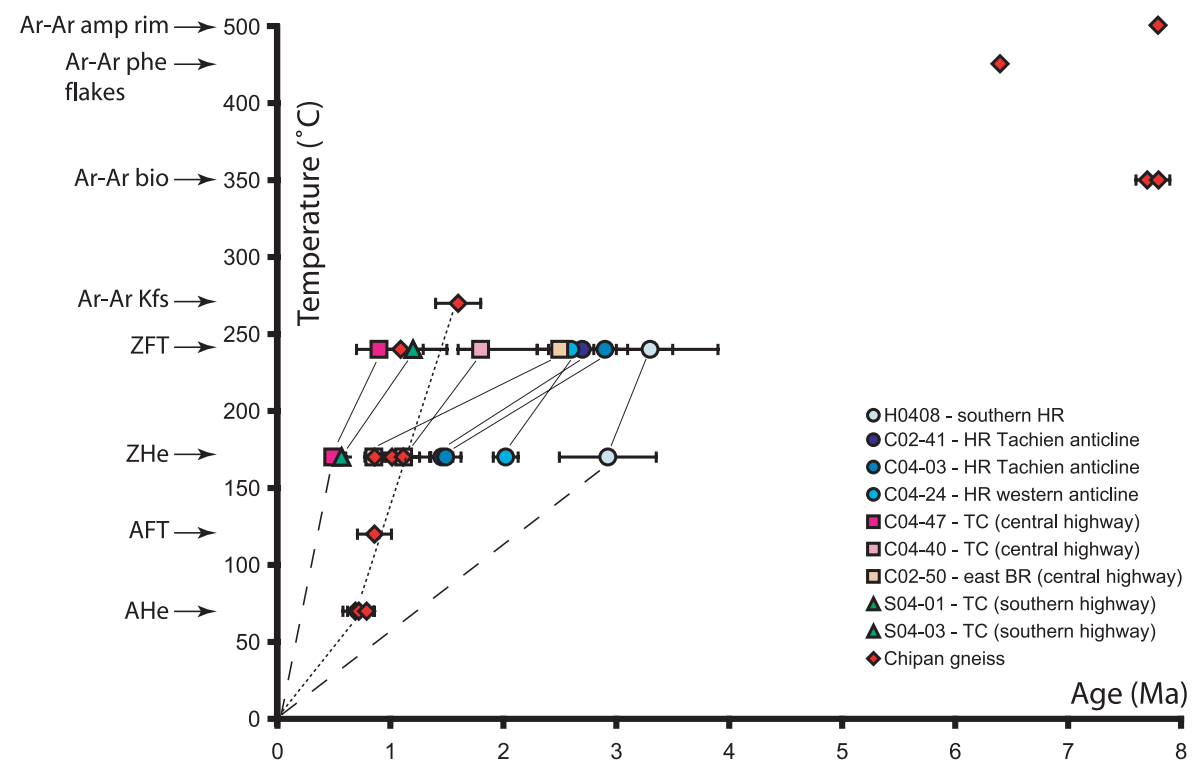

Figure 16. T-t diagram for different samples collected for (U-Th)/He thermometry. We use here the closure temperature proposed in the different source papers (see text for details). For each (U-Th)/He sample, the closest ZFT sample was taken from Liu et al. [2001]. For the Chipan gneiss, ${ }^{40} \mathrm{Ar} /{ }^{39} \mathrm{Ar}$ ages on biotite (Ar-Ar bio) and microcline (Ar-Ar Kfs), and ${ }^{40} \mathrm{Ar} /{ }^{39} \mathrm{Ar}$ age estimates for phengite flakes and for the reaction rims of amphiboles are from Lo and Onstott [1995]. Zircon fission track (ZFT) ages are central or $\chi 2$ ages [Liu et al., 2001], zircon (U-Th)/He ages are from this study $\left(180^{\circ} \mathrm{C}\right.$ closure temperature), and apatite fission track (AFT) central ages are from Willett et al. [2003].

the clay fraction of white micas, without differentiating several possible generations of these minerals. Moreover, in the case of such thin fractions $(<2 \mu \mathrm{m})$, the closure $\mathrm{T}$ of $350^{\circ} \mathrm{C}$ proposed in the source paper is most probably overestimated: a $\mathrm{T}$ of $250^{\circ}-280^{\circ} \mathrm{C}$ at most seems more realistic (P. Renne, personal communication, 2005). With regard to the $\mathrm{ZFT}$, pooled and $\chi^{2}$ ages (minimum ages) are generally similar in the study by Tsao [1996]. However, significant differences between central and $\chi^{2}$ ages are locally observed in the ZFT data obtained by Liu et al. [2001], who considered a larger amount of grains for each sample (Table S1). Detrital zircons in Taiwan have generally experienced a long and complex polymetamorphic history [e.g., Jahn et al., 1986; Ernst and Jahn, 1987] and may be severely physically altered. For these reasons, they are expected to exhibit various degrees of retentivity for fission tracks [Willett et al., 2003], even though the late Cenozoic peak $\mathrm{T}$ exceeded well the closure $\mathrm{T}$ for ZFT, as shown by RSCM $\mathrm{T}$ in both the TC and HR units. In addition, exhumation rates are high and show significant lateral variations over the Taiwan mountain belt. Altogether, these parameters may affect the degree of annealing of the zircon grains as well as the determination of a proper closure T. Central/pooled ages are usually provided but $\chi^{2}$ ages (minimum ages) are probably more meaningful as they eliminate the partially reset grains affected by these secondary processes. It should be emphasized here that specifying the kind of ZFT age chosen for any modeling is critical in the case of Taiwan because $\chi^{2}$ and central/pooled ages may show significant differences. Finally, a general consistency is observed between all thermochronometers given their usually attributed closure $\mathrm{T}$ : K-Ar ages are generally older than ZFT ages, which are themselves older than ZHe ages (Figures 5, 7, 9 and 13).

6.2.2. Temporal and Spatial Variations of Cooling Rates

[47] In Figure 16, we tentatively draw T-t paths for the different units of the Taiwan mountain belt, based on the data set compiled in this study. Closure $\mathrm{T}$ are those from the source papers. It should be pointed out that the different thermochronologic ages are taken from different studies and were therefore not obtained on the same samples. For each ZHe reset age of our study, we considered the closest available ZFT data from Liu et al. [2001], usually located within less than $1 \mathrm{~km}$ from our own samples. For the particular case of the Chipan gneiss, several dating techniques presented in separated studies were applied from lowtemperature thermochronometers to ${ }^{40} \mathrm{Ar}-{ }^{39} \mathrm{Ar}$ dating on various minerals. From this diagram, when considering the T-t path between $\mathrm{ZFT}\left(240^{\circ} \mathrm{C}\right)$ and $\mathrm{ZHe}\left(180^{\circ} \mathrm{C}\right)$ closure $\mathrm{T}$, it is interesting to note that all the samples from the $\mathrm{TC}$, including the Chipan gneiss, yield similar cooling rates in the range $100^{\circ}-120^{\circ} \mathrm{C} / \mathrm{Ma}$, except for our sample C04-47 showing a rate of $\sim 170^{\circ} \mathrm{C} / \mathrm{Ma}$. On the other hand, cooling rates largely vary spatially and temporally within the $\mathrm{HR}$ units and $\mathrm{BS}$. In the $240^{\circ} \mathrm{C}(\mathrm{ZFT})$ to $180^{\circ} \mathrm{C}(\mathrm{ZHe})$ range of $\mathrm{T}$, the western HR units of the northern profile and the southern termination of the HR unit (central profile) yield cooling rates of $\sim 120^{\circ} \mathrm{C} / \mathrm{Ma}$ and $\sim 185^{\circ} \mathrm{C} / \mathrm{Ma}$ respectively. Samples from the Tachien anticline (eastern HR units) and from eastern $\mathrm{BS}$ yield rates in the range $40^{\circ}-55^{\circ} \mathrm{C} / \mathrm{Ma}$. On 
the contrary, from $180^{\circ} \mathrm{C}(\mathrm{ZHe})$ back to the surface, the latter two cooled much faster than the former two. Despite the numerous uncertainties associated with such diagram, it provides first-order insights into cooling and exhumation of the Taiwan mountain belt. In particular, this diagram clearly indicates that because of significant spatial and temporal variations in cooling rates, interpretation of low-temperature thermochronometers in terms of exhumation and erosion rates requires at least a 2D-thermal model [Simoes et al., 2007].

\subsection{Tectonic Implications}

\subsubsection{Along-Strike Constant Pattern of Exhumation in} the Pilushan/Tananao System

[48] There is no break either in RSCM T or lowtemperature thermochronologic ages between the easternmost BS (mostly Pilushan) and the TC on both the northern and southern transects (Figures 5 and 13). This suggests that along-section these units had a laterally continuous evolution during the late Tertiary collision. On a first approximation, we observe that this ensemble does not show any significant along-strike variation in the pattern and magnitude of RSCM T and cooling ages (Figure 15), indicating that peak metamorphic $\mathrm{T}$ and the late exhumation history are probably similar from the southern to the northern transects. In the details, however, the Pilushan Formation is present to the east of the Taiwan mountain belt along the southern profile with RSCM-T lower than in the adjacent TC (Figure 15). Such almost constant along-strike pattern may suggest that the Pilushan/TC has evolved synchronously over the northern and the southern transects in Taiwan, in terms of intensity and timing of burial and of exhumation. This however contradicts the well-accepted southward propagation of the range growth. Alternatively, it can be proposed that the easternmost Taiwan mountain belt has reached close to a steady state in terms of peak metamorphic $\mathrm{T}$ and exhumation as defined by Willett and Brandon [2002]. South of our southernmost transect, the Pilushan/ TC ensemble may be still buried beneath the Miocene Lushan formation or any stratigraphic equivalent at the level of the Hengchun Peninsula (Figure 1). This implies a strong difference in terms of intensity of exhumation of these units between our studied area and the Hengchun peninsula, as also suggested by the thermochronologic data presented by Willett et al. [2003] and Fuller et al. [2006].

\subsubsection{Along-Strike Diachronous Evolution of the} Hsuehshan Range

[49] The spatial extent of the exhumed HR units narrows from the northern to the central transect (Figure 1). The HR units are absent along our southern transect because they are still not yet exhumed at the surface and are still probably buried beneath the BS and easternmost region of the southwestern foothills [Clark et al., 1993; Simoes and Avouac, 2006]. Along-strike variations in RSCM T and thermochronometric ages are also observed (Figure 15). Higher peak metamorphic $\mathrm{T}$ and younger cooling ages are found in the core of the Tachien anticline to the north. Going southward to the central transect, RSCM T decrease, and $\mathrm{ZFT} / \mathrm{ZHe}$ ages increase. Along the southern transect, these thermochronometers are not reset and RSCM T are below the $330^{\circ} \mathrm{C}$ resolution limit in the $\mathrm{BS}$ and probably also within the easternmost region of the southwestern foothills (Figures 5, 13 and 15). We interpret this pattern to reflect the northward increasing exhumation of the HR units (Figure 15). These observations also suggest that these units have probably not yet reached a geometric and exhumational steady state in the sense of Willett and Brandon [2002]. The northward exhumation of the HR units, as revealed from metamorphism and thermochronology, is also verified in the spatio-temporal evolution of the flexural response of the foreland basin to the growth of the Hsuehshan Range [Simoes and Avouac, 2006]. The differences between the patterns observed for TC and for the HR units suggest that exhumation of the TC is more longlived than that of the HR units, or else that exhumation rates are slower for the HR units.

\subsubsection{Implications for the Kinematics of Mountain- Building in Taiwan}

[50] As previously discussed, we believe that there is convincing evidence that RSCM T obtained in this study are representative of the last thermal event throughout the whole Taiwan mountain belt. We discuss here the tectonic implications of these findings with respect to late Cenozoic mountain building processes in Taiwan. We acknowledge that this interpretation may not be unique.

[51] The usually well-accepted model for mountain building in Taiwan is based on the critical wedge theory [Davis et al., 1983] and assumes that the mountain belt mostly grows by frontal accretion of material with only up to $25 \%$ underplating [Barr and Dahlen, 1989; Dahlen and Barr, 1989; Barr et al., 1991]. Such major contribution of frontal accretion to the growth of the eroding orogen implies that shortening is distributed throughout the whole mountain belt so as to maintain crustal thickening at the rear of the wedge. This model also predicts an eastward progressive increasing metamorphic grade across the mountain belt [Suppe, 1981; Barr et al., 1991]. In Figures 5, 7 and 13, we have reported the predictions of the thermo-kinematic model of Barr et al. [1991] in terms of peak metamorphic T and cooling ages. This model is able to reproduce the data over the TC only if some underplating is assumed at depth (at least $25 \%$ of accreted material, the maximum value initially assumed by these authors). However, it should be noted that a total shortening rate of $70 \mathrm{~mm} / \mathrm{yr}$ across the orogen was initially considered by Barr et al. [1991] in their model, a value too high in light of the $42 \mathrm{~mm} / \mathrm{yr}$ long-term shortening rate recently constrained by Simoes and Avouac [2006]. With a more reasonable value of $50 \mathrm{~mm} / \mathrm{yr}$ shortening rate across the orogen, Fuller et al [2006] were able to adjust the pattern of AFT and ZFT cooling ages in the eastern portion of the Taiwan mountain belt by assuming that $50 \%$ of the accreted material is underplated below the wedge. However, maximum peak $\mathrm{T}$ in their model are of $\sim 350^{\circ} \mathrm{C}$, too low in view of the $\sim 500^{\circ} \mathrm{C}$ found in the eastern Taiwan mountain belt from RSCM. As in Barr et al. [1991]'s study, Fuller et al. [2006] assumed a $9^{\circ} \mathrm{E}-10^{\circ} \mathrm{E}$ dipping decollement beneath the range, with maximum depths of $\sim 10$ to $15 \mathrm{~km}$ at the rear of the wedge. If underplating is maintained below TC to fit cooling ages, higher peak metamorphic $\mathrm{T}$ of $\sim 500^{\circ} \mathrm{C}$ can be obtained if 


\begin{tabular}{|c|c|}
\hline $\begin{array}{c}\text { N-S diachronous } \\
\text { evolution }\end{array}$ & $\begin{array}{c}\text { Synchronous evolution or } \\
\text { long-lived exhumation? }\end{array}$ \\
\hline
\end{tabular}

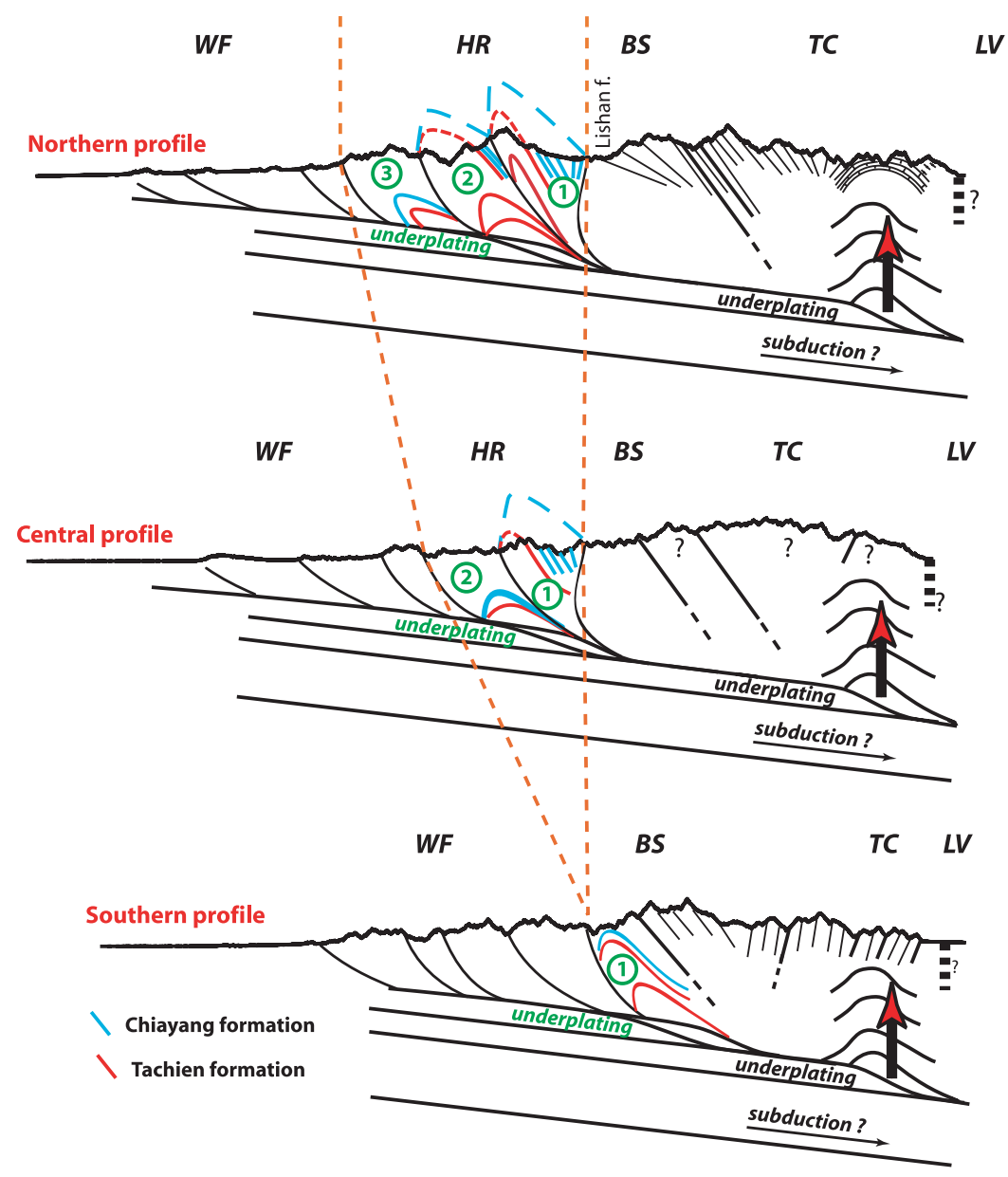

Figure 17. Schematic tectonic cross sections along the three studied transects. Note the synchronous and/or more long-lived exhumation of the Tananao complex and Pilushan formation, in contrast with the diachronous evolution and exhumation of the HR. WF, western foothills; HR, Hsuehshan Range units; BS, Backbone slates; TC, Tananao Complex; LV, longitudinal valley.

the decollement beneath Taiwan is steeper and reaches deeper levels. This has been suggested by Simoes and Avouac [2006] who found by balancing incoming and outcoming fluxes of material that the steady state mountain belt width observed in northern Taiwan can be reproduced with a $\sim 17^{\circ} \mathrm{E}$ steep decollement. This would imply a depth of $\sim 30 \mathrm{~km}$ beneath the TC, which can probably account for the high RSCM T of $\sim 500^{\circ} \mathrm{C}$ at the rear of the wedge. Although clear geophysical constraints on the geometry of the detachment are lacking, a robust implication of all these models and findings is that underplating should account for at least $\sim 50 \%$ of the incoming material. In fact, underplating has been proven to be an efficient mechanism to generate relatively high $\mathrm{T}$ and steep geothermal gradients in the lesser Himalaya of Nepal [Bollinger et al., 2004]. In any case, any of the models proposed in the literature fail to reproduce the important along-strike diachronous exhumation observed for the HR units. Indeed, exhumation of the HR units breaks the progressive eastward increase in metamorphic grade and in exhumation predicted by these previous studies (Figure 5). In addition, the strong along-strike variations observed in the exhumation of the HR units suggest that mountain building in Taiwan cannot be treated simply by assuming along-strike steady state. An alternative thermokinematic model accounting for the spatial and temporal variations in exhumation along-strike is therefore needed.

[52] We propose that the Taiwan mountain belt has grown essentially by underplating rather than by frontal accretion. Underplating occurs by the accretion of duplexes at the toe of the wedge [e.g., Dunlap et al., 1997; Willett et al., 2001; Bollinger et al., 2004; Konstantinovskaia and Malavieille, 2005]. This mechanism is consistent with the recent kine- 
matics of shortening across Taiwan determined by Simoes and Avouac [2006] over a timescale of $\sim 2$ Ma: because most of the shortening is absorbed on the most frontal faults of the foothills, underplating is needed below the Taiwan mountain belt to compensate for the loss of material by erosion. In Figure 17, we sketch a possible tectonic scenario of the growth of the Taiwan mountain belt, which accounts for the data and observations presented here. We represent three schematic cross-sections that correspond to the three transects investigated in this study. Because of the southward propagation of the collision, they may be viewed as imaging the equivalent temporal evolution of the wedge. In this model, the orogenic prism grows by underplating against a backstop corresponding to the CoR and LV. Underplating is not uniform and constant over the whole wedge: we propose that exhumation and uplift of the HR units and TC have been sustained through underplating, and that underplating should be negligible (if any) beneath the BS because of the very little exhumation observed. This model basically distinguishes the laterally diachronous exhumation of the HR units from the synchronous or steady state evolution of the BS and TC. Along the northern transect, both the high vertical movements due to underplating and westward exhumation of the HR units have generated two main anticlinal structures and probably a third one still buried beneath the Oligocene Paileng formation. The tectonic scenario proposed in Figure 17 is implemented and quantified in a thermo-kinematic model presented in a companion paper [Simoes et al., 2007].

\section{Conclusion}

[53] Combining RSCM thermometry and low-temperature thermochronology we have shown that the Taiwan mountain belt has undergone a significant regional thermal event during the late Cenozoic collision, except in the Miocene BS where exhumation has been limited. In the pre-Tertiary $\mathrm{TC}$, peak metamorphic $\mathrm{T}$ and the timing of exhumation are similar in northern and southern Taiwan. On the contrary, in the HR units, exhumation is minor to the south and increases northward, suggesting a diachronous evolution along strike. All models proposed in the literature fail in reproducing this along-strike evolution as well as the high $\mathrm{T}$ and exhumation of the HR units. We propose a tectonic scenario in which underplating plays a key role in the building of the mountain belt and varies along the section. In such scenario, two underplating windows are located beneath the TC and the Hsuehshan Range respectively. This mode of crustal thickening is observed in thermomechanical models [Toussaint et $a l ., 2004]$ and does allow for reconciling the observation that crustal thickening of the hinterland of mountain ranges generally occurs while most of the horizontal contraction occurs in the foreland fold-and-thrust belt, as derived by [Simoes and Avouac, 2006] for the Taiwan mountain belt. In a related paper [Simoes et al., 2007], we show that a thermokinematic model based on the scenario outlined here fits relatively well the data compiled in this study. Our study therefore places new constraints on the kinematics of mountain building in Taiwan, which should be considered in further modeling studies.

[54] Acknowledgments. We are indebted to Georges Rossman and Liz Miura-Boyd for access to the Raman laboratory at Caltech (California, USA) as well as for many instructive discussions. In the field we appreciated the help of Sylvain Bernard (ENS, France), Frank Yang, Chin-Ying Lan, Yu-ting Kuo, and Chung Huang as well as of many other students from NTU (Taiwan). The numerous thin sections were prepared by Roland Caron (ENS, France). The ZHe data were analyzed by Lindsey Hedges (Caltech). This study was improved thanks to the numerous discussions with Kerry Sieh, Bruce Shyu, and Mark Simons (Caltech), as well as with John Suppe (Princeton) and Jacques Malavieille (CNRS Montpellier). Mark Simons also collected the Chipan gneiss samples. Steve Kidder (Caltech) provided constructive comments on an early draft. This manuscript also benefited from the constructive and thoughtful reviews of Tim Byrne and Sean Willett, and from the comments of the Associate Editor K. Stuewe. This project was funded by the IT program (INSUCNRS, France) and by the Gordon and Betty Moore Foundation. This is Caltech Tectonics Observatory contribution 70 .

\section{References}

Agard, P., L. Jolivet, and B. Goffé (2001), Tectonometamorphic evolution of the Schistes lustrés complex: Implications for the exhumation of HP and UHP rocks in the western Alps, Bull. Soc. Geol. France, 172, 617-636.

Barr, T. D., and F. A. Dahlen (1989), Brittle frictional mountain building: 2. Thermal structure and heat budget, J. Geophys. Res., 94, 3923-3947.

Barr, T. D., F. A. Dahlen, and D. C. McPhail (1991), Brittle frictional mountain building: 3. Low-grade metamorphism, J. Geophys. Res., 96, 10,31910,338 .

Beyssac, O., B. Goffe, C. Chopin, and J.-N. Rouzaud (2002a), Raman spectra of carbonaceous material in metasediments: A new geothermometer, J. Metamorph. Geol., 20, 859-871.

Beyssac, O., J.-N. Rouzaud, B. Goffe, F. Brunet, and C. Chopin (2002b), Graphitization in a high-pressure, low-temperature metamorphic gradient: A Raman microspectroscopy and HRTEM study, Contrib. Mineral. Petrol., 143, 19-31.

Beyssac, O., et al. (2003a), On the characterization of disordered and heterogeneous carbonaceous materials using Raman spectroscopy, Spectrochim. Acta, Part A, 59, 2267-2276.
Beyssac, O., F. Brunet, J. P. Petitet, B. Goffé, and J. N. Rouzaud (2003b), Experimental study of the microtextural and structural transformations of carbonaceous materials under pressure and temperature, Eur. J. Mineral., 15, 937-951.

Beyssac, O., L. Bollinger, J. P. Avouac, and B. Goffe (2004), Thermal metamorphism in the Lesser Himalaya of Nepal determined from Raman spectroscopy of carbonaceous material, Earth Planet. Sci. Lett., $225,233-241$

Bollinger, L., J. P. Avouac, O. Beyssac, E. J. Catlos, T. M. Harrison, M. Grove, B. Goffé, and S. Sapkota (2004), Thermal structure and exhumation history of the Lesser Himalaya in central Nepal, Tectonics, 23, TC5015, doi:10.1029/2003TC001564.

Bollinger, L., P. Henry, and J. P. Avouac (2006), Mountain building in the Nepal Himalaya: Thermal and kinematic model, Earth Planet. Sci. Lett., 244, $58-$ 71.

Bousquet, R., R. Oberhänsli, B. Goffé, L. Jolivet, and O. Vidal (1998), High pressure-low temperature metamorphism and deformation in the "Bünderschiefer" of the Engadine window: Implications for the regional evolution of the eastern Central Alps, J. Metamorph. Geol., 16, 657-674.
Byrne, T. B., and C.-S. Liu (2002), Introduction to the geology and geophysics of Taiwan, in Geology and Geophysics of an Arc-Continent Collision, Taiwan, edited by T. B. Byrne and C.-S. Liu, Spec. Pap. Geol. Soc. Am., 358, 5-8.

Chi, W. R., J. Namson, and J. Suppe (1981), Stratigraphic record of plate interactions in the coastal range of eastern Taiwan, Mem. Geol. Soc. China, 4, 155-194.

Clark, M. B., D. M. Fisher, C.-Y. Lu, and C.-H. Chen (1993), Kinematic analyses of the Hsuehshan range, Taiwan: A large-scale pop-up structure, Tectonics, $12,205-217$

Crespi, J. M., Y.-C. Chan, and M. S. Swaim (1996), Synorogenic extension and exhumation of the Taiwan hinterland, Geology, 24, 247-250.

Dahlen, F. A., and T. D. Barr (1989), Brittle frictional mountain building: 1. Deformation and mechanical energy budget, J. Geophys. Res., 94, 3906-3922.

Davis, D., J. Suppe, and F. A. Dahlen (1983), Mechanics of fold-and-thrust belts and accretionary wedges, J. Geophys. Res., 88, 1153-1172.

Dunlap, W. J., G. Hirth, and C. Teyssier (1997), Thermomechanical evolution of a ductile duplex, Tectonics, 16, 983-1000. 
Dunn, S. R. (2005), Calcite-graphite isotope thermometry in amphibolite facies marble, Bancroft, Ontario, J. Metamorph. Geol., 23, 813-827.

Ernst, W. G. (1983), Mineral paragenesis in metamorphic rocks exposed along Tailuko Gorge, Central Moutain-range, Taiwan, J. Metamorph. Geol., I, $305-329$.

Ernst, W. G., and B. M. Jahn (1987), Crustal accretion and metamorphism in Taiwan, a post-Paleozoic mobile belt, Philos. Trans. R. Soc., Ser. A, 321 $129-161$.

Faure, M., C. Y. Lu, and H. T. Chu (1991), Ductile deformation and Miocene nappe-stacking in Taiwan related to motion of the Philippine Sea Plate, Tectonophysics, 198, 95-105.

Federico, L., G. Capponi, L. Crispini, M. Scambelluri, and I. M. Villa (2005), 39Ar/40Ar dating of highpressure rocks from the Ligurian Alps: Evidence for a continuous subduction-exhumation cycle, Earth Planet. Sci. Lett., 240, 668-680.

Fisher, D. M., C. Y. Lu, and H. T. Chu (2002), Taiwan Slate Belt: Insights into the ductile interior of an arc-continent collision, in Geology and Geophysics of an Arc-Continent Collision, Taiwan, edited by T. B. Byrne and C.-S. Liu, Spec. Pap. Geol. Soc Am., 358, 93-106.

Fuller, C. W., S. D. Willett, D. M. Fisher, and C. Y. Lu (2006), A thermomechanical wedge model of Taiwan constrained by fission-track thermochronometry, Tectonophysics, 425, 1-24.

Ho, C. S. (1986), A synthesis of the geologic evolution of Taiwan, Tectonophysics, 125, 1-16.

Ho, C. S. (1988), An Introduction to the Geology of Taiwan-Explanatory Text of the Geologic Map of Taiwan, 2nd ed., 192 pp., Central Geol. Surv., Taipei, China.

Holland, T. J. B., and R. Powell (1998), An internally consistent thermodynamic data set for phases of petrological interest, J. Metamorph. Geol., 16, $309-343$.

Hwang, S.-L., T.-F. Yui, H. T. Chu, and P. Shen (2001), Submicron polyphase inclusions in garnet from the Tananao metamorphic complex, Taiwan: A key to unravelling otherwise unrecognized metamorphic events, J. Metamorph. Geol., 19, 601-607.

Hwang, W.-T., and C.-Y. Wang (1993), Sequential thrusting model for mountain building: constraints from geology and heat flow of Taiwan, J. Geophys. Res., 98, 9963-9973

Jahn, B. M., J. G. Liou, and H. Nagasawa (1981), Highpressure metamorphic rocks of Taiwan: REE geochemistry, $\mathrm{Rb}-\mathrm{Sr}$ ages and tectonic implications, Mem. Geol. Soc. China, 4, 497-520.

Jahn, B. M., F. Martineau, J. J. Peucat, and J. Cornichet (1986), Geochronology of the Tananao schist complex, Taiwan, and its regional tectonic significance, Tectonophysics, 125, 103-124.

Juang, W. S., and H. Bellon (1986), Potassium-argon ages of the Tananao schist in Taiwan, Mem. Geol. Soc. China, 7, 405-416.

Konstantinovskaia, E., and J. Malavieille (2005), Erosion and exhumation in accretionary orogens: Experimental and geological approaches, Geochem. Geophys. Geosyst., 6, Q02006, doi:10.1029/2004GC000794.

Lee, J.-C., J. Angelier, and H. T. Chu (1997), Polyphase history and kinematics of a complex major fault zone in the northern Taiwan mountain belt: The Lishan fault, Tectonophysics, 274, 97-115.

Lin, A. T., A. B. Watts, and S. P. Hesselbo (2003), Cenozoic stratigraphy and subsidence history of the South China Sea margin in the Taiwan region, Basin Res., 15, 453-478.

Liou, J. G., C. O. Ho, and T. P. Yen (1975), Petrology of some glaucophane schists and related rocks from Taiwan, J. Petrol., 16, 80-109.

Liou, J. G., W. G. Ernst, and D. E. Moore (1981), Geology and petrology of some polymetamorphosed amphibolites and associated rocks in Northeastern Taiwan-Summary, Geol. Soc. Am. Bull., $219,219-224$.

Liu, T.-K., S. Hsieh, Y.-G. Chen, and W-.S. Chen (2001), Thermo-kinematic evolution of the Taiwan oblique-collision mountain belt as revealed by zircon fission-track dating, Earth Planet. Sci. Lett., $186,45-56$.

Lo, C.-H., and T. C. Onstott (1995), Rejuvenation of $\mathrm{K}$-Ar systems for minerals in the Taiwan mountain belt, Earth Planet. Sci. Lett., 131, 71-98.

Lo, C.-H., and T.-F. Yui (1996), 40Ar/39Ar dating of high-pressure rocks in the Tananao basement complex, Taiwan, J. Geol. Soc. China, 39, 13-30.

Malavieille, J., and G. Trullenque (2007), Consequences of continental subduction on forearc basin and accretionnary wedge deformation in SE Taiwan: Insights from analogue modelling, Tectonophysics, in press.

Malavieille, J., et al. (2002), Arc-continent collision in Taiwan: New marine observations and tectonic evolution, Spec. Pap. Geol. Soc. Am., 358, 189 213.

Negro, F., O. Beyssac, B. Goffé, O. Saddiqi, and M. Bouybaouene (2006), Thermal structure of the Alboran Domain in the Rif (northern Morocco) and the Western Betics (southern Spain): Constraint from Raman spectroscopy of carbonaceous material, J. Metamorph. Geol., 24, 309-327.

Page, B. M., and J. Suppe (1981), The Pliocene Lichi Melange of Taiwan: Its olistostromal and platetectonic origin, Am. J. Sci., 281, 193-227.

Pulver, M. H., J. M. Crespi, and T. B. Byrne (2002), Lateral extrusion in a transpressional collision zone: An example from the pre-Tertiary metamorphic basement of Taiwan, in Geology and Geophysic of an Arc-Continent Collision, Taiwan, edited by T. B. Byrne and C. S. Liu, Spec. Pap. Geol. Soc. Am., 358, 107-120.

Reiners, P. W., T. L. Spell, S. Nicolescu, and K. A Zanetti (2004), Zircon (U-Th)/He thermochronometry: He diffusion and comparisons with (super 40) $\mathrm{Ar} /$ (super 39)Ar dating, Geochim. Cosmochim. Acta, 68, 1857-1887.

Sella, G. F., T. H. Dixon, and A. Mao (2002), REVEL: A model for recent plate velocities from space geodesy, J. Geophys. Res., 107(B4), 2081, doi:10.1029/ 2000JB000033

Shyu, J. B. H., K. Sieh, and Y.-G. Chen (2005a), Neotectonic architecture of Taiwan and its implications for future large earthquakes, J. Geophys. Res., 110 B08402, doi:10.1029/2004JB003251.

Shyu, J. B. H., K. Sieh, and Y.-G. Chen (2005b), Tandem suturing and disarticulation of the Taiwan orogen revealed by its neotectonic elements, Earth Planet. Sci. Lett., 233, 167-177.

Shyu, J. B. H., K. Sieh, Y.-G. Chen, and L.-H. Chung (2006), Geomorphic analysis of the Central Range fault, the second major active structure of the Longitudinal Valley suture, eastern Taiwan, Geol. Soc. Am. Bull., 118, 1447-1462.

Sibuet, J. C., and S. K. Hsu (2004), How was Taiwan created?, Tectonophysics, 379, 159-181.

Simoes, M., and J. P. Avouac (2006), Investigating the kinematics of mountain building in Taiwan from the spatiotemporal evolution of the foreland basin and western foothills, J. Geophys. Res., 111, B10401, doi: $10.1029 / 2005$ JB004209

Simoes, M., J. P. Avouac, O. Beyssac, B. Goffe, K. A. Farley, and Y.-G. Chen (2007), Mountain building in Taiwan: A thermokinematic model, J. Geophys. Res., doi:10.1029/2006JB004824, in press.

Spear, F. S. (1993), Metamorphic phase equilibria and pressure-temperature-time paths, Mineral. Soc. Monogr., 1, 799 pp.

Stanley, R. S., L. B. Hill, H. C. Chang, and H. N. Hu (1981), A cross-section through the southern centra mountains of Taiwan, Mem. Geol. Soc. China, 4 $443-474$.

Suppe, J. (1976), Decollement folding in Southwestern Taiwan, Pet Geol. Taiwan, 13, 26-35.

Suppe, J. (1981), Mechanics of mountain building and metamorphism in Taiwan, Mem. Geol. Soc. China, 4, 67-89.

Suppe, J. (1984), Kinematics of arc-continent collision, flipping of subduction, and back-arc spreading near Taiwan, Mem. Geol. Soc. China, 6, 21-33.
Sweeney, J. J., and A. K. Burnham (1990), Evaluation of a simple-model of vitrinite reflectance based on chemical kinetics, AAPG Bull., 74, 1559-1570.

Tillman, K. S., and T. B. Byrne (1995), Kinematic analysis of the Taiwan Slate Belt., Tectonics, 14, 322-341.

Tillman, K. S., and T. B. Byrne (1996), Out-ofsequence thrusting in the Taiwan slate belt, J. Geol. Soc. China, 39, 189-208.

Toussaint, G., E. B. Burov, and L. Jolivet (2004), Continental plate collision: unstable vs. stable slab dy namics, Geology, 32, 33-36.

Tsao, S. J. (1996), The geological significance of illite crystallinity, zircon fission-track ages and $\mathrm{K}-\mathrm{Ar}$ ages of metasedimentary rocks of the Central Range., Ph.D. thesis, 272 pp., Natl. Taiwan Univ., Taipei.

Wang, P. L., L. H. Lin, and C. H. Lo (1998), 40Ar/39Ar dating of mylonitization in the Tananao schist, eastern Taiwan, J. Geol. Soc. China, 41, 159-183.

Warneke, L. A., and W. G. Ernst (1984), Progressive Cenozoic metamorphism of rocks cropping out along the southern east-west cross-island highway, Taiwan, Mem. Geol. Soc. China, 6, 105-132.

Willett, S. D., and M. T. Brandon (2002), On steadystates in mountain belts, Geology, 30, 175-178.

Willett, S. D., D. M. Fisher, and E.-C. Yeh (2001), High erosion rates in Taiwan from apatite and zircon fission track ages, paper presented at Earth System Processes-Global Metting, Geol. Soc. of Am., Boulder, Colo.

Willett, S. D., D. M. Fisher, C. W. Fuller, Y. En-Chao, and L. Chia-Yu (2003), Erosion rates and orogenicwedge kinematics in Taiwan inferred from fissiontrack thermochronometry, Geology, 31, 945-948.

Wopenka, B., and J. D. Pasteris (1993), Structural characterization of kerogens to granulite-facies graphite: Applicability of Raman microprobe spectroscopy, Am. Mineral., 78, 533-557.

Yue, L.-F., J. Suppe, and J-.H. Hung (2005), Structural geology of a classic thrust belt earthquake: The 1999 Chi-Chi earthquake Taiwan $(\mathrm{Mw}=7.6)$, J. Struct. Geol., 27, 2058-2083.

Yui, T. F. (2005), Isotopic composition of carbonaceous material in metamorphic rocks from the mountain belt of Taiwan, Int. Geol. Rev, 47, 310-325.

Yui, T. F., and C. H. Lo (1989), High-pressure metamorphosed ophiolitic rocks from the Wanjung area, Taiwan, Chung-kuo Ti Chih Hsueh Hui Hui K'an, $32,47-62$.

Yui, T. F., E. Huang, and J. Xu (1996), Raman spectrum of carbonaceous material: A possible metamorphic grade indicator for low-grade metamorphic rocks, J. Metamorph. Geol., 14, 115-124.

Zhou, D., H.-S. Yu, H.-H. Xu, X.-B. Shi, and Y.-W. Chou (2003), Modeling of thermo-rheological structure of lithosphere under the foreland basin and mountain belt of Taiwan, Tectonophysics, $374,115-134$.

J. P. Avouac and K. A. Farley, Tectonics Observatory, Geological and Planetary Sciences Division, California Institute of Technology, Mail code 100-23, Pasadena, CA 91125, USA. (farley@gps.caltech.edu; avouac@gps.caltech.edu)

O. Beyssac and B. Goffé, Laboratoire de Géologie, Ecole Normale Supérieure, CNRS, 24 rue Lhomond, F-75005 Paris, France. (beyssac@geologie.ens.fr; bruno. goffe@cnrs-dir.fr)

Y.-G. Chen, Geosciences Department, National Taiwan University, No. 1, Sec. 4 th, Roosevelt Rd. Taipei 106, Taiwan. (ygchen@ntu.edu.tw)

Y.-C. Chan, Institute of Earth Sciences, Academia Sinica, 128 Academia Road, Sec. 2, Nankang, Taipei 115, Taiwan. (yuchang@earth.sinica.edu.tw)

M. Simoes, Géosciences Rennes, Université Rennes 1_CNRS, Rennes, France. (martine.simoes@univ rennes1.fr) 